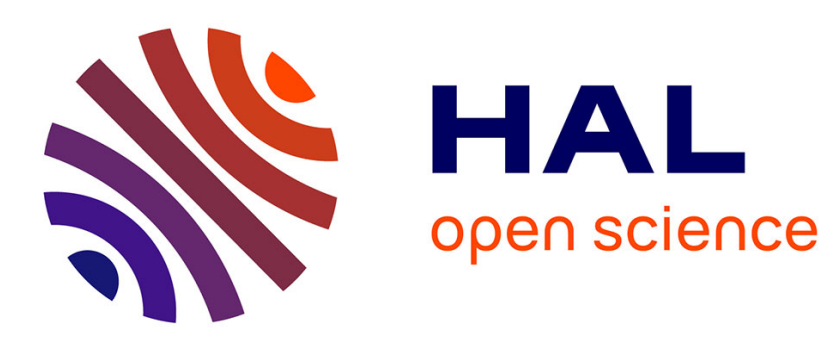

\title{
Transition-Metal Complexes Based on the 1,3,5-Triethynyl Benzene Linking Unit
}

Heinrich Lang

\section{To cite this version:}

Heinrich Lang. Transition-Metal Complexes Based on the 1,3,5-Triethynyl Benzene Linking Unit. Journal of Inorganic and General Chemistry / Zeitschrift für anorganische und allgemeine Chemie, 2010, 636 (15), pp.2607. 10.1002/zaac.201000243 . hal-00574817

\section{HAL Id: hal-00574817 https://hal.science/hal-00574817}

Submitted on 9 Mar 2011

HAL is a multi-disciplinary open access archive for the deposit and dissemination of scientific research documents, whether they are published or not. The documents may come from teaching and research institutions in France or abroad, or from public or private research centers.
L'archive ouverte pluridisciplinaire HAL, est destinée au dépôt et à la diffusion de documents scientifiques de niveau recherche, publiés ou non, émanant des établissements d'enseignement et de recherche français ou étrangers, des laboratoires publics ou privés. 


\section{Transition-Metal Complexes Based on the 1,3,5-Triethynyl Benzene Linking Unit}

\begin{tabular}{|r|l|}
\hline Journal: & Zeitschrift für Anorganische und Allgemeine Chemie \\
\hline Manuscript ID: & zaac.201000243 \\
\hline Wiley - Manuscript type: & Article \\
\hline $\begin{array}{r}\text { Date Submitted by the } \\
\text { Author: }\end{array}$ & 16 -Jun-2010 \\
\hline Complete List of Authors: & Lang, Heinrich; der TU Chemnitz, Institut fẪ r Chemie \\
\hline Keywords: & $\begin{array}{l}\text { Heteromultimetallic, Transition Metals, Acetylide, Ferrocene, Solid } \\
\text { State Structure }\end{array}$ \\
\hline \multicolumn{2}{|l}{} \\
\hline
\end{tabular}

\section{S scholaroNE" \\ Manuscript Central}


 \\ Transition-Metal Complexes Based on the 1,3,5-Triethynyl Benzene Linking Unit
}

\section{Rico Packheiser, Tobias Rüffer, Petra Ecorchard, and Heinrich Lang*)}

Chemnitz, Technische Universität, Fakultät für Naturwissenschaften, Institut für Chemie, Lehrstuhl für Anorganische Chemie

Bei der Redaktion eingegangen am ...

\begin{abstract}
The synthesis of a unique series of heteromultinuclear transition metal compounds is reported. Complexes 1-I-3-Br-5-(FcC $\equiv C)-\mathrm{C}_{6} \mathrm{H}_{3} \quad(4), 1-\mathrm{Br}-3-(\mathrm{bpy}-\mathrm{C} \equiv \mathrm{C})-5-(\mathrm{FcC} \equiv \mathrm{C})-\mathrm{C}_{6} \mathrm{H}_{3} \quad(\mathbf{6})$, 1,3-(bpy-C $\equiv C)_{2}-5-(\mathrm{FcC} \equiv \mathrm{C})-\mathrm{C}_{6} \mathrm{H}_{3} \quad(7), \quad 1-(\mathrm{XC} \equiv \mathrm{C})-3-(\mathrm{bpy}-\mathrm{C} \equiv \mathrm{C})-5-(\mathrm{FcC} \equiv \mathrm{C})-\mathrm{C}_{6} \mathrm{H}_{3} \quad(\mathbf{8}, \quad \mathrm{X}=$ $\left.\mathrm{SiMe}_{3} ; \mathbf{9}, \mathrm{X}=\mathrm{H}\right), 1-(\mathrm{HC} \equiv \mathrm{C})-3-\left[(\mathrm{CO})_{3} \mathrm{ClRe}(\mathrm{bpy}-\mathrm{C} \equiv \mathrm{C})\right]-5-(\mathrm{FcC} \equiv \mathrm{C})-\mathrm{C}_{6} \mathrm{H}_{3}(\mathbf{1 1}), 1-\left[\left(\mathrm{Ph}_{3} \mathrm{P}\right) \mathrm{Au}-\right.$ $\mathrm{C} \equiv \mathrm{C}]-3-\left[(\mathrm{CO})_{3} \mathrm{ClRe}(\mathrm{bpy}-\mathrm{C} \equiv \mathrm{C})\right]-5-(\mathrm{FcC} \equiv \mathrm{C})-\mathrm{C}_{6} \mathrm{H}_{3} \quad(\mathbf{1 3}), \quad 1-\left[\left(\mathrm{Ph}_{3} \mathrm{P}\right) \mathrm{AuC} \equiv \mathrm{C}\right]-3-(\mathrm{bpy}-\mathrm{C} \equiv \mathrm{C})-5-$ $(\mathrm{FcC} \equiv \mathrm{C})-\mathrm{C}_{6} \mathrm{H}_{3} \quad(\mathbf{1 4}), \quad\left[1-\left[\left(\mathrm{Ph}_{3} \mathrm{PAuC} \equiv \mathrm{C}\right]-3-\left[\left\{[\mathrm{Ti}]\left(\mathrm{C} \equiv \mathrm{CSiMe}_{3}\right)_{2}\right\} \mathrm{Cu}(\mathrm{bpy}-\mathrm{C} \equiv \mathrm{C})\right]-5-(\mathrm{FcC} \equiv \mathrm{C})-\right.\right.$ $\left.\mathrm{C}_{6} \mathrm{H}_{3}\right] \mathrm{PF}_{6}(\mathbf{1 6})$, and $\left[1,3-\left[\left(t-\mathrm{Bu}_{2} \mathrm{bpy}\right)_{2} \mathrm{Ru}(\mathrm{bpy}-\mathrm{C} \equiv \mathrm{C})\right]_{2}-5-(\mathrm{FcC} \equiv \mathrm{C})-\mathrm{C}_{6} \mathrm{H}_{3}\right]\left(\mathrm{PF}_{6}\right)_{4}(\mathbf{1 8})\left(\mathrm{Fc}=\left(\eta^{5}-\right.\right.$
\end{abstract}


$\left.\mathrm{C}_{5} \mathrm{H}_{4}\right)\left(\eta^{5}-\mathrm{C}_{5} \mathrm{H}_{5}\right) \mathrm{Fe}$, bpy = 2,2'-bipyridiyl-5-yl, [Ti] = $\left.\left(\eta^{5}-\mathrm{C}_{5} \mathrm{H}_{4} \mathrm{SiMe}_{3}\right)_{2} \mathrm{Ti}\right)$ were prepared by using consecutive synthesis methodologies including metathesis, desilylation, dehydrohalogenation, and carbon-carbon cross-coupling reactions. In these complexes the corresponding metal atoms are connected via carbon-rich bridging units comprising 1,3-diethynyl-, 1,3,5triethynylbenzene and bipyridyl units. They have been characterized by elemental analysis, IR and NMR spectroscopy, and partly by ESI-TOF mass spectrometry.

The structures of $\mathbf{4}$ and $\mathbf{1 1}$ in the solid state are reported. Both molecules are characterized by the central benzene core bridging the individual transition metal complex fragments. The corresponding acetylide entities are, as typical, found in a linear arrangement with representative $\mathrm{M}-\mathrm{C}, \mathrm{C}-\mathrm{C}_{\mathrm{C} \equiv \mathrm{C}}$ and $\mathrm{C} \equiv \mathrm{C}$ bond distances.

\author{
* Prof. Dr. H. Lang \\ Techn. Universität \\ Inst. f. Chemie, Anorganische Chemie \\ Straße der Nationen 62 \\ D-09111 Chemnitz \\ E-mail: heinrich.lang@chemie.tu-chemnitz.de. Phone: (+49)371-531-21210. Fax: (+49)371- \\ 531-21219.
}

Keywords: Heteromultimetallic; Solid State Structure; Transition Metals; Acetylide; Ferrocene.

\title{
Introduction
}

The synthesis of carbon-rich acetylide-containing molecules opens new avenues of fundamental and technological research at the interface between chemistry and materials science. 
Unusual structures, high stability and useful electronic properties are some of the desirable fundamental characteristics of such systems which have captured much attention during the last years [1]. In this context, interest centers on those compounds that contain next to the carbon-rich structural units redox-active metal building blocks, among which the ferrocenyl moiety has been most studied. The ferrocenyl group is, for example, robust, represents a oneelectron reservoir and can undergo reversible redox processes [2]. Very recently, ferrocenyl entities, $\left(\eta^{5}-\mathrm{C}_{5} \mathrm{H}_{4}\right)\left(\eta^{5}-\mathrm{C}_{5} \mathrm{H}_{5}\right) \mathrm{Fe}$, were successfully applied in the synthesis of heteromultimetallic transition metal complexes in which the metal atoms are bridged by carbon-rich connectivities [3]. While homo- and heterobimetallic complexes with carbon-rich organic and/or inorganic connecting units have been designed and synthesized, and their chemical and physical properties intensively studied $[4,5]$, only less is known about organometallics in which more than three different metals are linked by organic $\pi$-conjugated bridging ligands [3]. Such molecules are of great interest, due to their extended organic $\pi$-system which can provide remarkable applications and hence, the electrochemical behavior, UV-Vis/NIR characteristics and EPR analysis of in-situ generated associated radical cations have been studied [6 - 8].

As an extension of our previous work in the field of heteromultimetallic chemistry in which we connected different early and late transition metal atoms with carbon-rich organic and inorganic bridging units, we here focus on some further straightforward synthesis methods for the preparation and characterization of diverse unsymmetrical compounds featuring the transition metals $\mathrm{Ti}, \mathrm{Re}, \mathrm{Fe}, \mathrm{Ru}, \mathrm{Cu}$, and $\mathrm{Au}$, and comprising 1,3,5-triethynylbenzene and 2,2'bipyridiyl-5-yl (= bpy) organic connecting units. The structure of two molecules in the solid state is discussed as well. 


\section{Results and Discussion}

In terms of synthesizing heteromultimetallic transition metal complexes based on the 1,3,5triethynylbenzene core, we chose ferrocenyl-functionalized $1-\mathrm{I}-3-\mathrm{Br}-5-(\mathrm{FcC} \equiv \mathrm{C})-\mathrm{C}_{6} \mathrm{H}_{3}$ (4) as suitable key starting material. Organometallic 4 was synthesized by subsequent treatment of 1-I-3,5- $\mathrm{Br}_{2}-\mathrm{C}_{6} \mathrm{H}_{3}$ (1) with $\mathrm{FcC} \equiv \mathrm{CH}$ (2) under Sonogashira cross-coupling conditions to produce $1,3-\mathrm{Br}_{2}-5-\mathrm{FcC} \equiv \mathrm{C}-\mathrm{C}_{6} \mathrm{H}_{3}(3)$ which on $\mathrm{Br}-\mathrm{I}$ exchange eventually resulted in the formation of 4 (Scheme 1) [7].

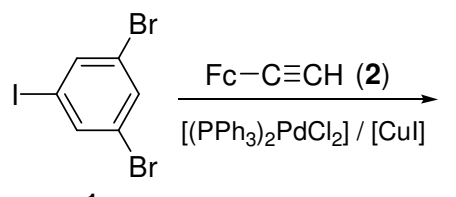

1

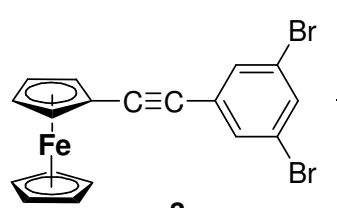

3

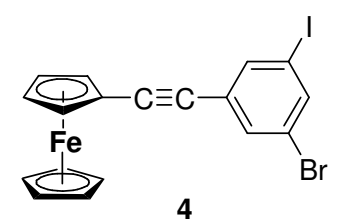

4

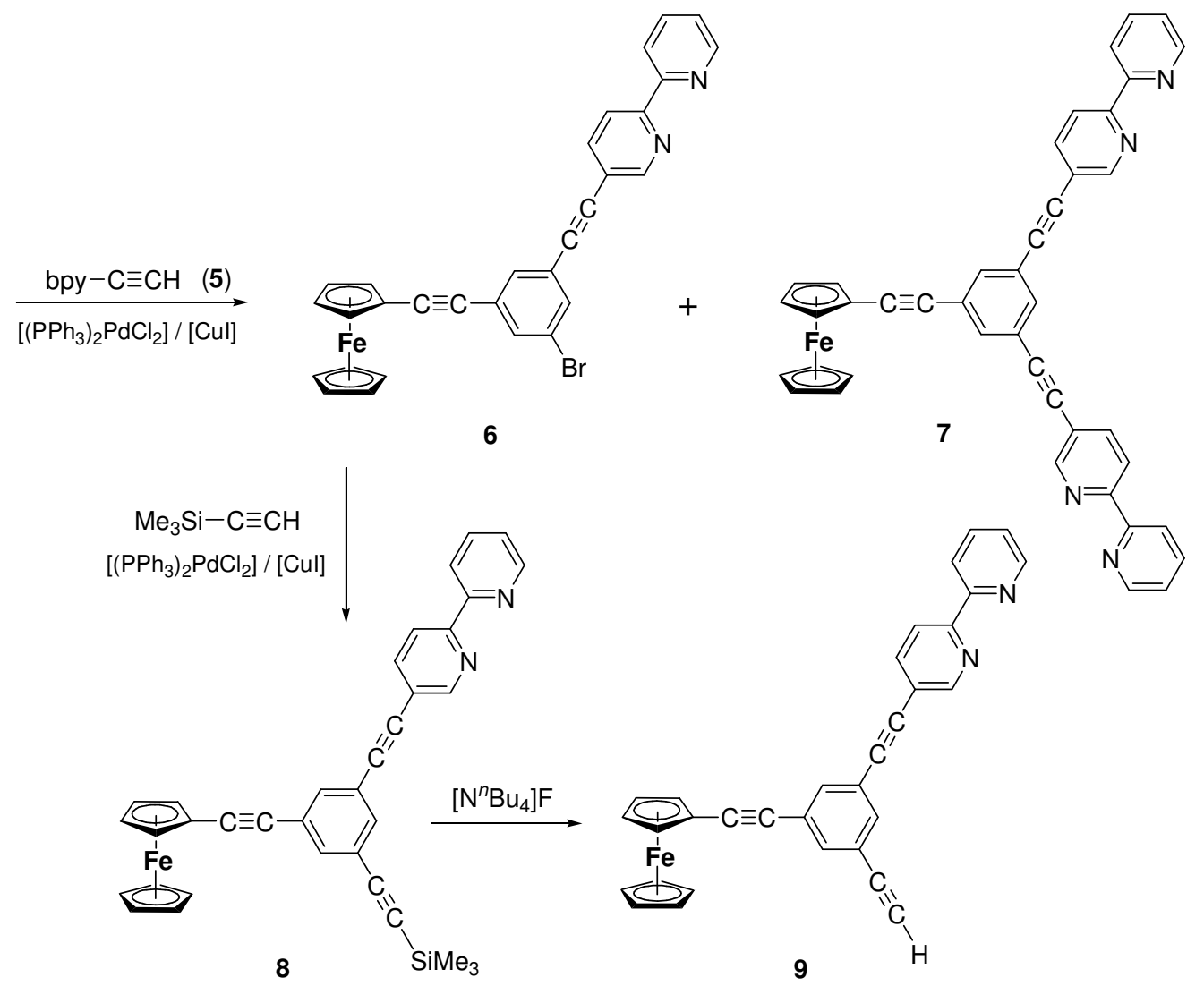

Scheme 1. Consecutive reaction sequence for the synthesis of 9. 
The diethynyl-substituted compound 1-Br-3-(bpy-C $\equiv \mathrm{C})-5-(\mathrm{FcC} \equiv \mathrm{C})-\mathrm{C}_{6} \mathrm{H}_{3}(\mathbf{6})$ was accessible by the reaction of 4 with one equivalent of 5-ethynyl-2,2-bipyridine (5) under typical Sonogashira carbon-carbon cross-coupling conditions (diisopropylamine, $40{ }^{\circ} \mathrm{C}$ ), whereby the more reactive aryl-iodo bond allowed the preferential introduction of one 5-ethynyl-2,2bipyridyl moiety (Scheme 1, Experimental Part). After appropriate work-up, mononuclear 6 was isolated as an orange solid in $78 \%$ yield. As side product the corresponding disubstituted molecule 1,3-(bpy-C $\equiv \mathrm{C})_{2}-5-(\mathrm{FcC} \equiv \mathrm{C})-\mathrm{C}_{6} \mathrm{H}_{3}(7)$ could be isolated in a yield of $7 \%$ (Experimental Part). The exchange of one $\mathrm{Br}$ substituent by the more reactive jodide in $\mathbf{3}$ was necessary to obtain complex $\mathbf{6}$ as major product. If $\mathbf{3}$ was reacted under similar reaction conditions with bpyC $\equiv \mathrm{CH}(5)$ a mixture of $\mathbf{6}$ and 7 was obtained. Complex $\mathbf{6}$ was further reacted with an excess of trimethylsilylacetylene under similar reaction conditions whereby the reaction mixture had to be heated to $80{ }^{\circ} \mathrm{C}$ for completion and hence, forming 1 -( $\left.\mathrm{Me}_{3} \mathrm{SiC} \equiv \mathrm{C}\right)-3-(\mathrm{bpy}-$ $\mathrm{C} \equiv \mathrm{C})-5-(\mathrm{FcC} \equiv \mathrm{C})-\mathrm{C}_{6} \mathrm{H}_{3}(\mathbf{8})$. Desilylation of $\mathbf{8}$ with $\left[n-\mathrm{Bu}_{4} \mathrm{~N}\right] \mathrm{F}$ in tetrahydrofuran at ambient temperature finally gave $1-(\mathrm{HC} \equiv \mathrm{C})-3-(\mathrm{bpy}-\mathrm{C} \equiv \mathrm{C})-5-(\mathrm{FcC} \equiv \mathrm{C})-\mathrm{C}_{6} \mathrm{H}_{3} \quad$ (9) as a yellow solid (Scheme 1).

With its different functionalities, organometallic 9 was used as starting material for the synthesis of higher nuclear transition metal complexes featuring up to four different metal atoms as outlined in Scheme 2.

The synthesis of $1-\left[\left(\mathrm{Ph}_{3} \mathrm{P}\right) \mathrm{AuC} \equiv \mathrm{C}\right]-3-\left[(\mathrm{CO})_{3} \mathrm{ClRe}(\mathrm{bpy}-\mathrm{C} \equiv \mathrm{C})\right]-5-(\mathrm{FcC} \equiv \mathrm{C})-\mathrm{C}_{6} \mathrm{H}_{3}$ (Scheme 2) includes following steps: (i) treatment of 9 with equimolar amounts of $\left[\operatorname{Re}(\mathrm{CO})_{5} \mathrm{Cl}\right](\mathbf{1 0})$ in toluene and heating the reaction medium for 8 hours to $60{ }^{\circ} \mathrm{C}$ gave 1 $(\mathrm{HC} \equiv \mathrm{C})-3-\left[(\mathrm{CO})_{3} \mathrm{ClRe}(\right.$ bpy-C$\left.\equiv \mathrm{C})\right]-5-(\mathrm{FcC} \equiv \mathrm{C})-\mathrm{C}_{6} \mathrm{H}_{3}(\mathbf{1 1})$, which in the next step (ii) afforded on addition of $\left[\left(\mathrm{Ph}_{3} \mathrm{P}\right) \mathrm{AuCl}\right](\mathbf{1 2})$ in presence of catalytic amounts of [CuI] complex $\mathbf{1 3}$ in which the three complex fragments $\mathrm{Fc}$, (bpy) $\mathrm{Re}(\mathrm{CO})_{3} \mathrm{Cl}$, and $\left(\mathrm{Ph}_{3} \mathrm{P}\right) \mathrm{Au}$ are connected via a 1,3,5-triethynylbenzene core (Scheme 2). 
Even the synthesis of a heterotetrametallic complex featuring $\mathrm{Ti}, \mathrm{Fe}, \mathrm{Cu}$, and $\mathrm{Au}$ metal atoms is possible by starting from 9. In this respect, heterobimetallic 1-[( $\left.\left.\mathrm{Ph}_{3} \mathrm{P}\right) \mathrm{AuC} \equiv \mathrm{C}\right]-3-(\mathrm{bpy}-$ $\mathrm{C} \equiv \mathrm{C})-5-(\mathrm{FcC} \equiv \mathrm{C})-\mathrm{C}_{6} \mathrm{H}_{3}(\mathbf{1 4})$ was prepared using a mixture of tetrahydrofruan-diethylamine of ratio $1: 1$ at $25{ }^{\circ} \mathrm{C}$ (Scheme 2). It was necessary to add a catalytic amount of [CuI] to the reaction medium for completion of the reaction [8]. The last step in the synthesis of [1$\left.\left[\left(\mathrm{Ph}_{3} \mathrm{P}\right) \mathrm{AuC} \equiv \mathrm{C}\right]-3-\left[\left\{[\mathrm{Ti}]\left(\mathrm{C} \equiv \mathrm{CSiMe}_{3}\right)_{2}\right\} \mathrm{Cu}(\mathrm{bpy}-\mathrm{C} \equiv \mathrm{C})\right]-5-(\mathrm{FcC} \equiv \mathrm{C})-\mathrm{C}_{6} \mathrm{H}_{3}\right] \mathrm{PF}_{6} \quad(\mathbf{1 6})\left([\mathrm{Ti}]=\left(\eta^{5}-\right.\right.$ $\left.\mathrm{C}_{5} \mathrm{H}_{4} \mathrm{SiMe}_{3}\right)_{2} \mathrm{Ti}$ ) included the addition of the heterobimetallic organometallic $\pi$-tweezer molecule $\left[\left\{[\mathrm{Ti}]\left(\mu-\sigma, \pi-\mathrm{C} \equiv \mathrm{CSiMe}_{3}\right)_{2}\right\} \mathrm{Cu}(\mathrm{N} \equiv \mathrm{CMe})\right] \mathrm{PF}_{6}$ (15) to 14. On replacement of the only weakly-bonded acetonitrile by the 2,2'-bipyridyl ligand, heterotetrametallic 16, after appropriate work-up, was obtained as a red solid material in good yield (Scheme 2, Experimental Part).

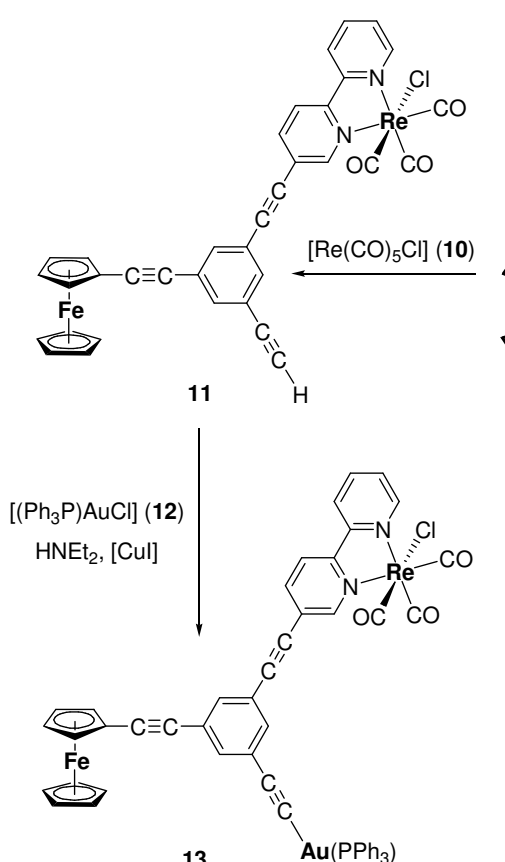

13
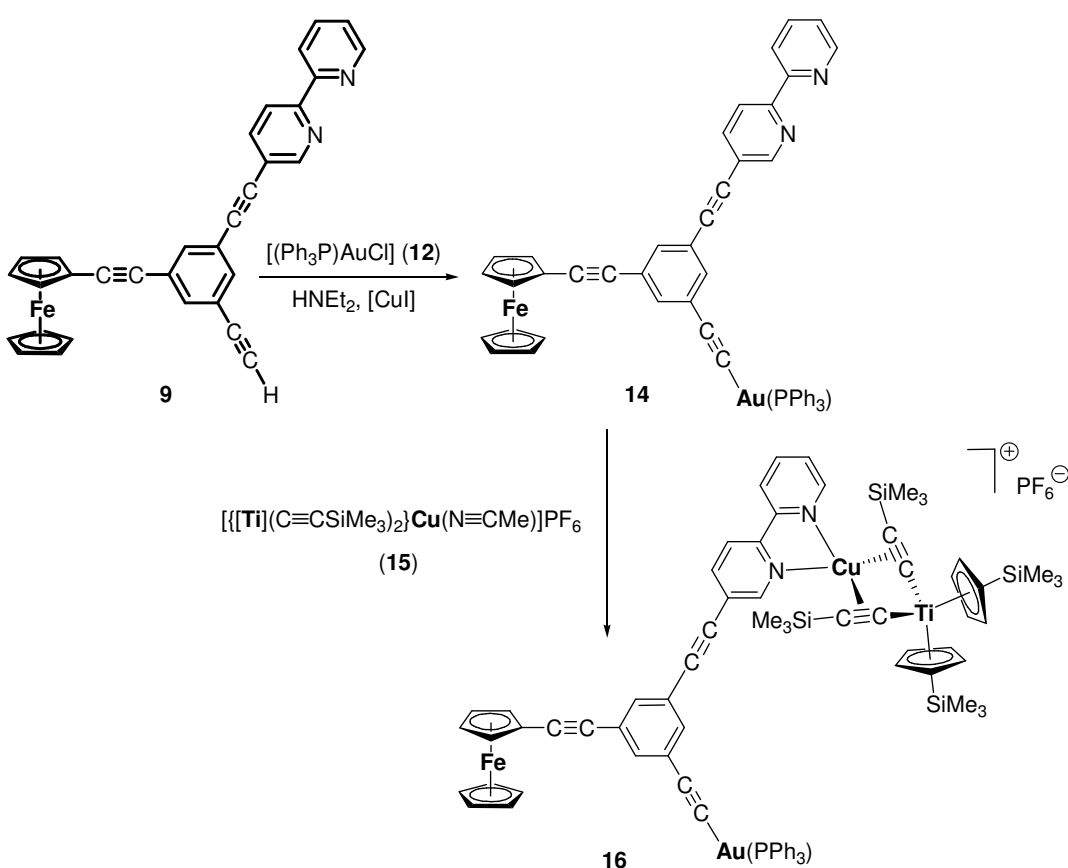

Scheme 2. Synthesis of heterometallic $\mathbf{1 3}$ and $\mathbf{1 6}$ using $\mathbf{9}$ as key starting material.

The synthesis of a trimetallic $\mathrm{FeRu}_{2}$ species, $\left[1,3-\left[\left(t-\mathrm{Bu} \mathrm{u}_{2} \text { bpy }\right)_{2} \mathrm{Ru}(\mathrm{bpy}-\mathrm{C} \equiv \mathrm{C})\right]_{2}-5-(\mathrm{FcC} \equiv \mathrm{C})-\right.$ $\left.\mathrm{C}_{6} \mathrm{H}_{3}\right]\left(\mathrm{PF}_{6}\right)_{4}(\mathbf{1 8})\left(t\right.$-Bu $\mathrm{B}_{2}$ bpy = 4,4`-di-tert.-butyl-2,2`-bipyridyl) was possible by reacting 1,3- 


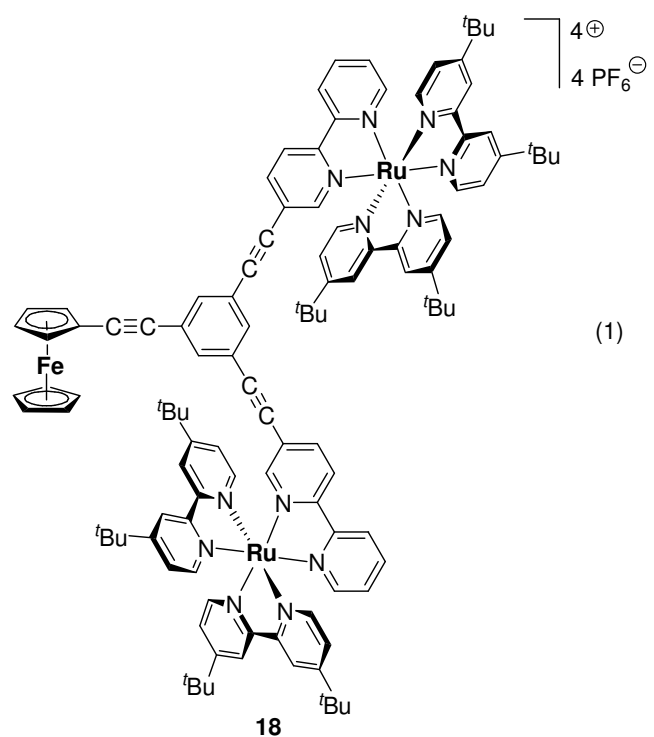

All new synthesized multimetallic transition metal complexes are stable both in solid state and solution, with exception of $\mathbf{1 6}$. This molecule slowly decomposes in solution over prolonged time on precipitation of non-soluble materials in common organic solvents.

The identities of $4,6-9,11,13,14,16$, and 18 have been confirmed by elemental analysis, IR, ${ }^{1} \mathrm{H},{ }^{13} \mathrm{C}\left\{{ }^{1} \mathrm{H}\right\},{ }^{31} \mathrm{P}\left\{{ }^{1} \mathrm{H}\right\}$ NMR spectroscopy, and partly by ESI-TOF mass spectrometry. The structure of complexes $\mathbf{4}$ and 11, respectively, in the solid state was additionally determined by single-crystal X-ray structure analysis, thus confirming the structural assignment made from spectroscopic characterization.

The IR spectra of all compounds are characterized by very dominant $v_{\mathrm{C} \equiv \mathrm{C}}$ vibrations of the organometallic $\mathrm{M}-\mathrm{C} \equiv \mathrm{CR}\left(\mathrm{M}=\mathrm{Ti}, \mathrm{Au}, \mathrm{Fc} ; \mathrm{R}=\mathrm{C}_{6} \mathrm{H}_{3}, \mathrm{SiMe}_{3}\right)$ and the organic $\mathrm{X}-\mathrm{C} \equiv \mathrm{C}-\mathrm{C}_{6} \mathrm{H}_{3}(\mathrm{X}$ 
$=\mathrm{H}$, bpy, $\mathrm{C}_{5} \mathrm{H}_{4}$ ) units (Experimental Part). These vibrations are found in the range of $2157-$ $2214 \mathrm{~cm}^{-1}$ for the organic moieties, while for the metal acetylide fragments typical absorptions are observed at $2115(\mathrm{AuC} \equiv \mathrm{C})$ [9] and $1924 \mathrm{~cm}^{-1}(\mathrm{TiC} \equiv \mathrm{C})$ [10], respectively. For the $\mathrm{HC} \equiv \mathrm{C}$ group present in 9 an additional strong absorption band is found at $3290 \mathrm{~cm}^{-1}$. Furthermore, in the IR spectra of the corresponding metal-carbonyl molecules $\mathbf{1 1}$ and $\mathbf{1 3}$ the CO stretching vibrations are very diagnostic and represent a useful monitoring tool along with the appearance and disappearance of the $v_{\mathrm{H}-\mathrm{C} \equiv \mathrm{C}}$ vibration (complex 11 vs. 13). For 11 and $\mathbf{1 3}$ three (11: 1894,1914 , and $2022 \mathrm{~cm}^{-1} ; \mathbf{1 3}: 1896,1915$, and $2021 \mathrm{~cm}^{-1}$ ) very strong $v_{\mathrm{CO}}$ bands are observed which is typical for this type of species [11].

The consecutive formation of the multimetallic assemblies from $\mathbf{3}$ and $\mathbf{4}$ is also confirmed by ${ }^{1} \mathrm{H}$ NMR spectroscopic studies (Experimental Part). Characteristic for all compounds is the appearance of typical ferrocenyl signals at ca. $4.25 \mathrm{ppm}$ (singlet) for the $\mathrm{C}_{5} \mathrm{H}_{5}$ ring protons and between $4.2-4.6 \mathrm{ppm}$ (pseudo-triplets) for the $\mathrm{C}_{5} \mathrm{H}_{4}$ protons with a $J_{\mathrm{HH}}$ coupling constant of ca. $1.9 \mathrm{~Hz}$ (Experimental Part). The titanium-bonded cyclopentadienyl ligands in 16 are observed between $6.2-6.3 \mathrm{ppm}$ as multiplet differing from the starting material $\mathbf{1 5}$, where pseudo-triplets are characteristic. [12] The ${ }^{1} \mathrm{H}$ NMR spectrum of 9 consists of a singlet at 3.14 ppm which can be assigned to the acetylenic proton. The bpy, $\mathrm{C}_{6} \mathrm{H}_{3}$, and $\mathrm{C}_{6} \mathrm{H}_{5}$ groups give typical resonances with the anticipated chemical shifts and coupling patterns (Experimental Part). For example, the aryl protons of the central phenylene ring were found as three separated pseudo-triplets in the range of $7.4-7.8$ ppm showing up-field shifts upon coordination of the alkynyl units to a transition metal fragment (Experimental Part). Most significant for 8 is the appearance of a resonance signal at $0.26 \mathrm{ppm}$ for the trimethylsilyl group. In this context, most diagnostic for the formation of $\mathbf{1 6}$ is the high-field shift $(-0.48 \mathrm{ppm})$ of the $\mathrm{Me}_{3} \mathrm{SiC} \equiv \mathrm{C}$ protons in comparison to $\mathbf{1 5}$ upon coordination of the bipyridyl entity to the organometallic $\pi$-tweezer copper(I) center which can be explained by the ring current of the Wiley- $\stackrel{8}{ } \mathrm{CH}$ 
chelating bipyridyl ligand $[12,13]$. In addition, as a result of the different chemical environment, the spectrum of $\mathbf{1 6}$ reveals two well separated singlets at 0.28 and $0.30 \mathrm{ppm}$ for the cyclopentadienyl-bonded $\mathrm{Me}_{3} \mathrm{Si}$ units (Experimental Part). Similar observations were made in the ${ }^{13} \mathrm{C}\left\{{ }^{1} \mathrm{H}\right\}$ NMR spectra of the complexes described above.

The ${ }^{31} \mathrm{P}\left\{{ }^{1} \mathrm{H}\right\}$ NMR spectra of the $\left(\mathrm{Ph}_{3} \mathrm{P}\right) \mathrm{Au}$-containing molecules 13, 14, and $\mathbf{1 6}$ show a singlet at ca. $41.5 \mathrm{ppm}$ indicative of simlar phosphine environments. Compared to the starting material $\left[\left(\mathrm{Ph}_{3} \mathrm{P}\right) \mathrm{AuCl}\right](\mathbf{1 2})(33.8 \mathrm{ppm}[14])$ a shift to lower field is observed which is typical for exchanging the gold(I)-bonded chloride by an acetylide unit [9]. The non-coordinating $\mathrm{PF}_{6}^{-}$ion in 16 gives rise to a septet at $-145.1 \mathrm{ppm}$ with ${ }^{1} J_{\mathrm{PF}}=713 \mathrm{~Hz}$.

For multimetallic complexes $\mathbf{1 3}$ and $\mathbf{1 6}$ electrospray ionization mass spectrometric investigations indicated the presence of the appropriate molecular ions $[\mathrm{M}+\mathrm{H}]^{+}(\mathrm{m} / z, 1253.4, \mathbf{1 3})$, $\left[\mathrm{M}-\mathrm{PF}_{6}\right]^{+}(\mathrm{m} / z, 1525.3, \mathbf{1 6})$ with characteristic isotope distribution patterns. Characteristic for 18 is the molecular ion $\left[\mathrm{M}-4 \mathrm{PF}_{6}\right]^{4+}(\mathrm{m} / \mathrm{z}, 479.2)$ and the formation of fragments such as $[\mathrm{M}-$ $\left.4 \mathrm{PF}_{6}-\mathrm{Ru}\left(t-\mathrm{Bu}_{2} \mathrm{bpy}\right)_{2}\right]^{2+}(\mathrm{m} / z$ 639.6) (Experimental Part).

Additionally, the molecular structures of $\mathbf{4}$ and $\mathbf{1 1}$ in the solid state were determined by single crystal X-ray diffraction. Single crystals could be obtained by slow diffusion of $n$-hexane into a chloroform solution containing either $\mathbf{4}$ or $\mathbf{1 1}$ at ambient temperature. The perspective drawings with the atomic numbering scheme of these molecules are shown in Figures 1 and 2 (4) and Figures 3 - 5 (11) together with selected bond distances $(\AA)$ and bond angles $\left({ }^{\circ}\right)$. The crystallographic data are summarized in Table 1 (Experimental Part). 
Both complexes $\mathbf{4}$ and $\mathbf{1 1}$ crystallize in the monoclinic space group $\mathrm{P}_{2} 1 / \mathrm{n}$. From Figures 1 and 3 it can be seen that the structures of $\mathbf{4}$ and $\mathbf{1 1}$ are essentially similar as far as the molecule backbone is concerned.

As typical for other ferrocenyl complexes the Fe1-D1 and Fe1-D2 separations in $\mathbf{4}$ and $\mathbf{1 1}$ are found between 1.640(4) and 1.654(4) $\AA$ [15]. The two cyclopentadienyl ligands are thereby rotated by $0.1(6)^{\circ}(\mathbf{4})$ and $2.5(7)^{\circ}(\mathbf{1 1})$ with respect to each other, which verifies an almost eclipsed conformation. The $\mathrm{Fc}-\mathrm{C} \equiv \mathrm{C}-,\left((\mathrm{CO})_{3} \mathrm{ClRe}\right)$ bpy-C $\equiv \mathrm{C}-$, and $\mathrm{HC} \equiv \mathrm{C}$ - acetylide units are, as expected, linear with typical $\mathrm{C} \equiv \mathrm{C}$ separations (Figures 1 and 3 ). The bond distances and bond angles for all the other groups agree well with those reported elsewhere, and therefore it is not necessary to discuss them separately [11, 15].

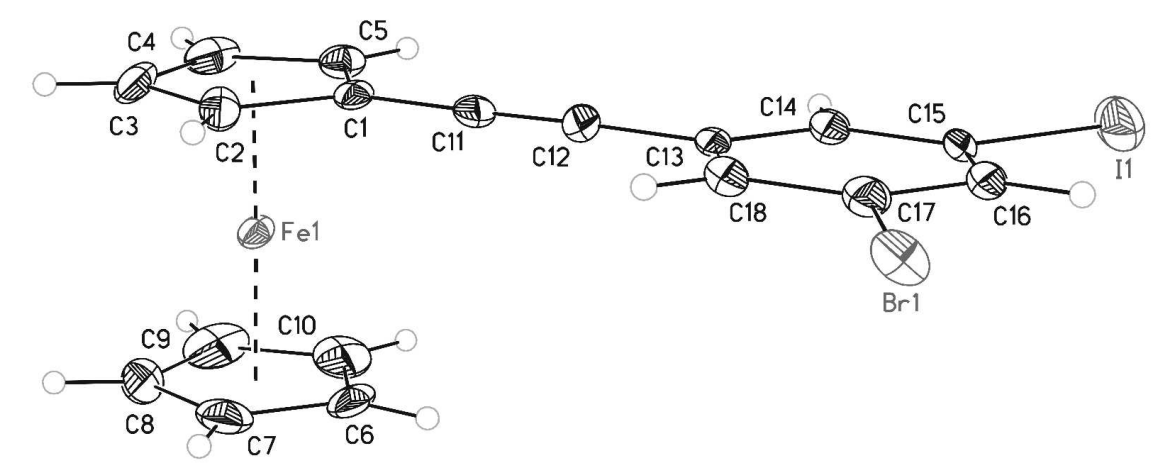

Figure 1. The molecular solid state structure (ORTEP diagram, 50\% probability level) of 4 with the atom numbering scheme. Hydrogen atoms are omitted for clarity. Selected bond distances $(\AA)$ and bond angles $\left({ }^{\circ}\right)$ : Fe1-D1 1.644(4), Fe1-D2 1.654(4), C11-C12 1.206(12), C17-Br1 1.947(9), C15-I1 2.031(8); C1-C11C12 178.6(8), C11-C15-C13 178.4(8). D1 = centroid of C1 - C5, D2 = centroid of C6 - C10. Standard uncertainties of the last significant digit(s) are shown in parenthesis. 
Molecule 4 possesses in the solid state $\pi$ - $\pi$-interactions between the $\mathrm{C}_{5} \mathrm{H}_{5}$ ring and the $\mathrm{C}_{6} \mathrm{H}_{3}$ ring of the next molecule. This gives rise to the formation of $1 \mathrm{D}$ chains along the crystallographic $a$-axis (Figure 2).

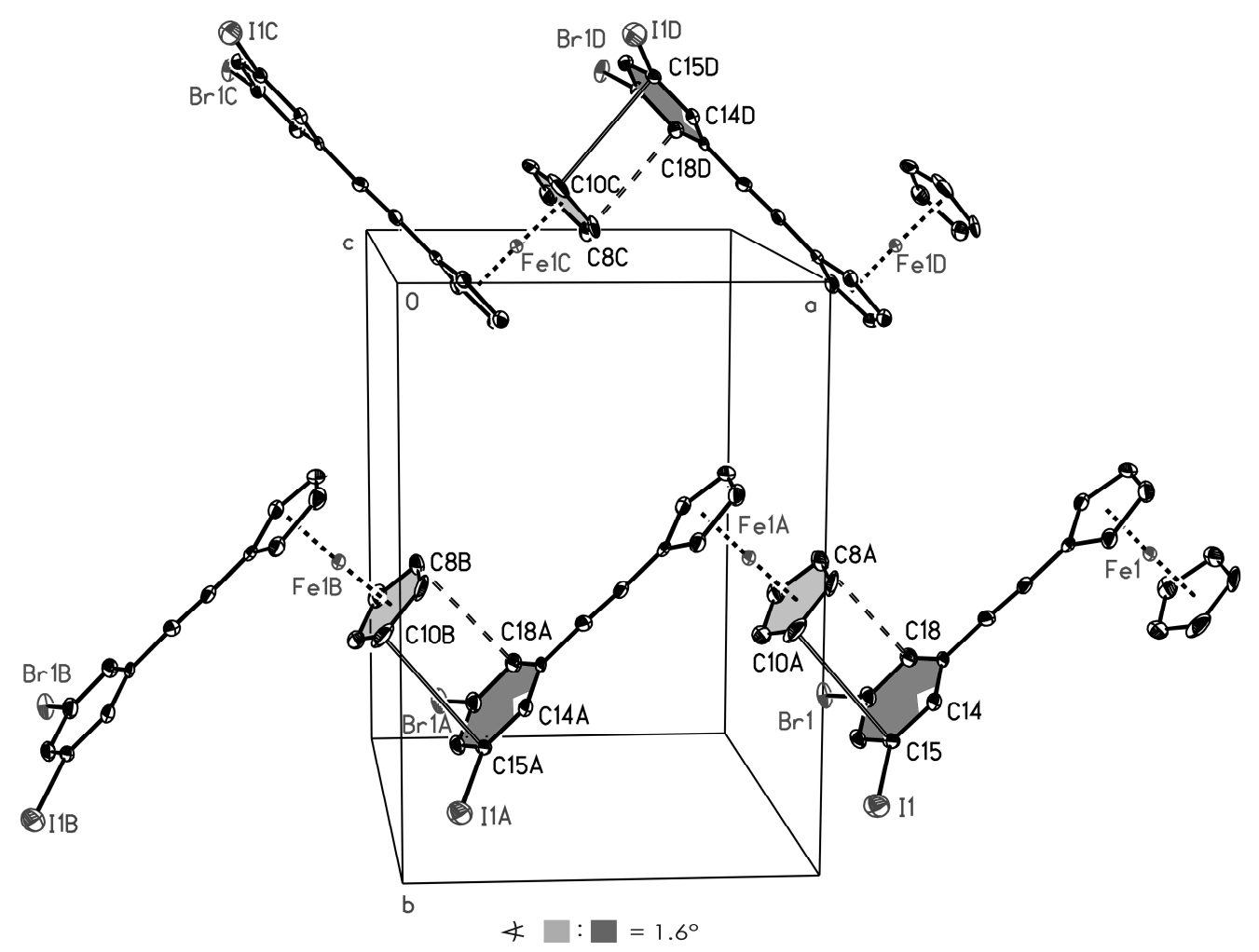

Figure 2. Graphical representation of the $\pi$ - $\pi$-interactions of molecules of $\mathbf{4}$ in the solid state giving rise to the formation of $1 \mathrm{D}$ chains along the crystallographic $a$-axis. Dotted lines refer to the shortest $(3.480 \AA)$ and dashed lines to the longest $\mathrm{C}-\mathrm{C}$ contacts (3.561 $\AA$ ) of interacting cyclopentadienyl and phenyl rings with $\Varangle$ giving the interplanar angle. Labels ' $A$ ' to ' $D$ ' refer to the $1^{\text {st }}-4^{\text {th }}$ symmetry generated molecules of 4 . Hydrogen atoms are omitted for clarity.

Most obvious, the structure of $\mathbf{1 1}$ in the solid state shows a somewhat distorted octahedral geometry around Re1 with three carbonyl ligands, arranged in a facial fashion. The N1-Re1$\mathrm{N} 2$ angle at $74.8(2)^{\circ}$ is significantly less than $90^{\circ}$, as required by the bite distance exerted by the steric demand of the chelating bipyridyl building block (Figure 3). Similar observations 
were made for other bpy-containing rhenium transition metal complexes, including 1-[(t$\left.\left.\mathrm{Bu}_{2} \mathrm{bpy}\right)(\mathrm{CO})_{3} \mathrm{ReC} \equiv \mathrm{C}\right]-3,5-(\mathrm{HC} \equiv \mathrm{C})_{2}-\mathrm{C}_{6} \mathrm{H}_{3}[1 \mathrm{~s}]$.

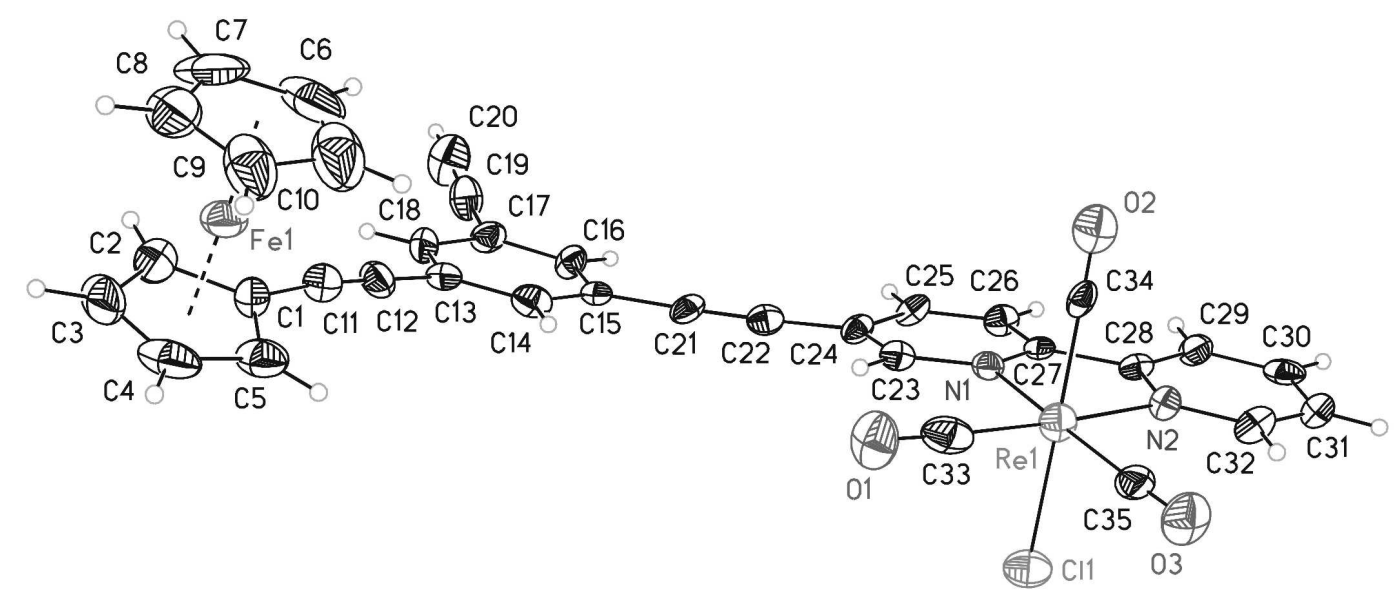

Figure 3. The molecular solid state structure (ORTEP diagram, $50 \%$ probability level) of 11 with the atom numbering scheme. Hydrogen atoms are omitted for clarity. Selected bond distances $(\AA)$ and bond angles $\left(^{\circ}\right)$ : Fe1-D1 1.646(4), Fe1-D2 1.640(4), C11-C12 1.176(9), C19-C20 1.188(11), C21-C22 1.212(10), Re1-N1 2.166(5), Re1-N2 2.184(6), Re1-Cl1 2.471(2), Re1-C33 1.904(9), Re1-C34 1.935(8), Re1C35 1.917(9), C33-O1 1.171(9), C34-O2 1.120(8), C35-O3 1.156(9); C1-C11C12 174.3(8), C11-C12-C13 178.0(9), C17-C19-C20 173.9(10), C15-C21-C22 177.5(8), C21-C22-C24 177.8(9), N1-Re1-N2 74.8(2), C33-Re1-C35 89.1(3), C34-Re1-C11 176.5(2). D1 = centroid of C1 - C5, D2 = centroid of C6 - C10. Standard uncertainties of the last significant digit(s) are shown in parenthesis.

Furthermore molecule $\mathbf{1 1}$ forms in the solid state a 1D chain set up by $\pi$ - $\pi$-interactions among the pyridyl and phenyl rings as it can be seen from Figures 4 and 5 . The shortest distances are thereby $3.339 \AA$, which represents a quite strong interaction [16]. 


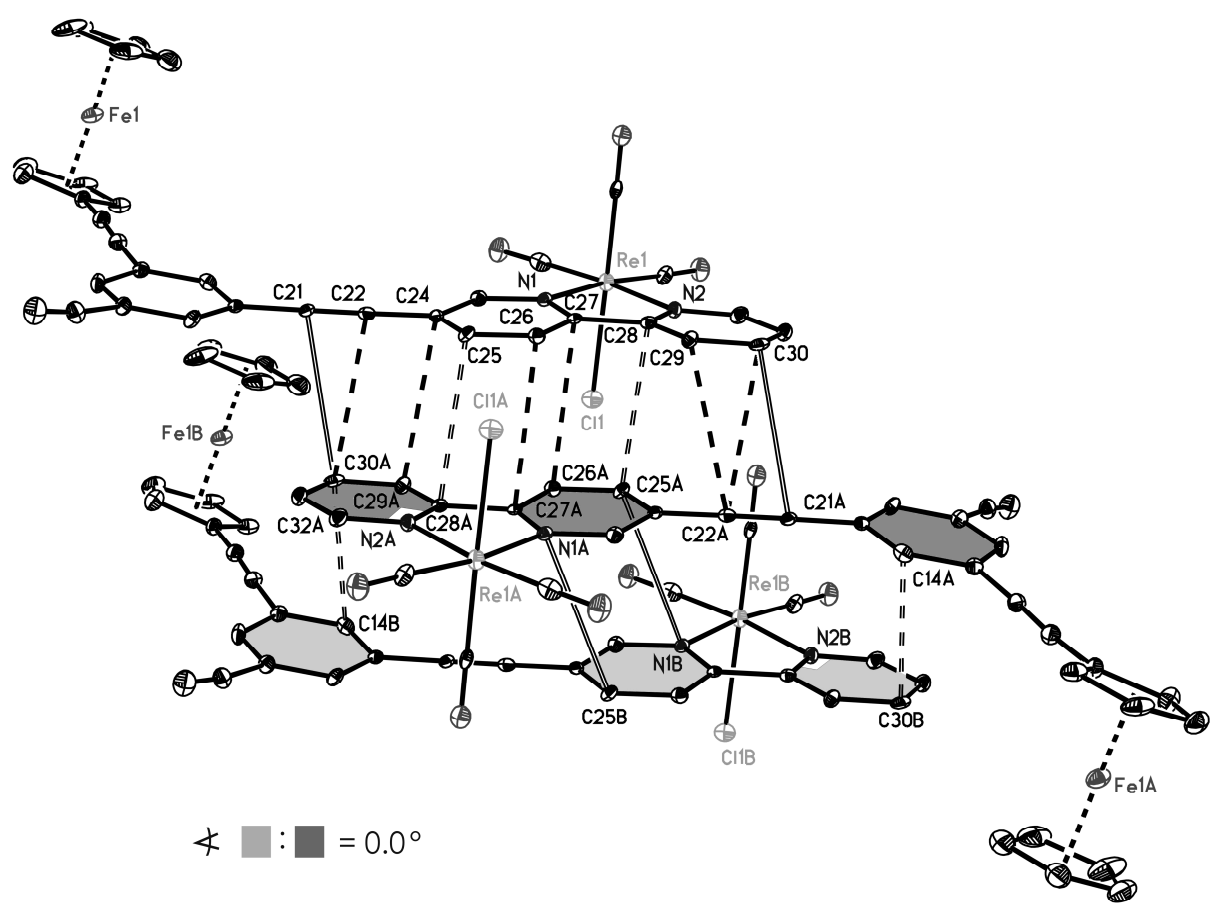

Figure 4. Graphical illustration of the repeating unit of the $1 \mathrm{D}$ chains formed by $\mathbf{1 1}$ in the solid state. Labels ' $A$ ' and ' $B$ ' refer to a $1^{\text {st }}$ and a $2^{\text {nd }}$ symmetry generated molecule of 11. Dotted lines indicate interactions of carbon atoms of $\mathbf{1 1}$ and $\mathbf{1 1 A}$, while the dashed lines representing the longest $(3.427 \AA)$ and open lines representing the shortest (3.367 ̊) distances. 11A/11B: Dashed lines the longest (3.558 $\mathrm{A})$ and open lines the shortest (3.339 ̊) distances.

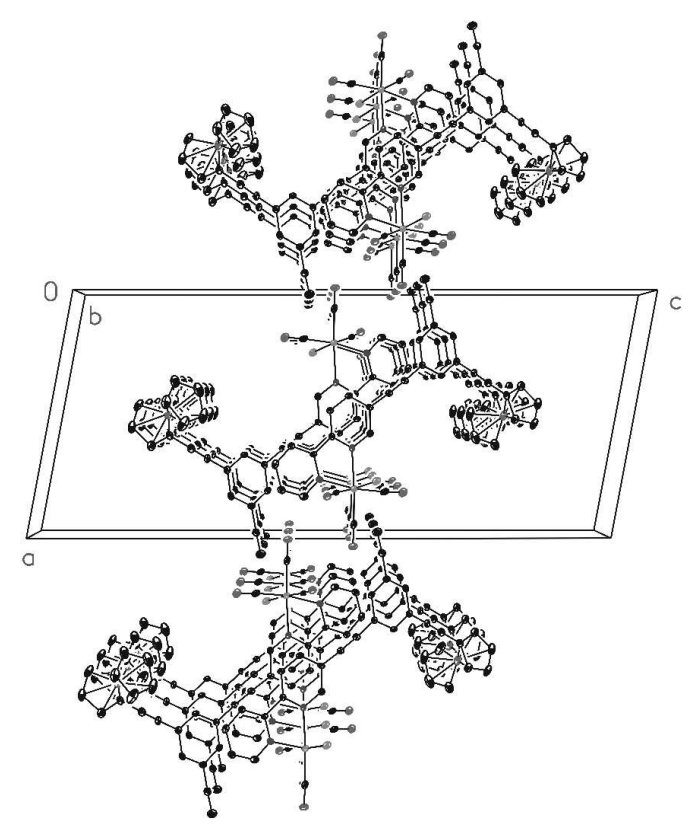


Figure 5. Graphical illustration of the alignment of $1 \mathrm{D}$ chains formed by $\mathbf{1 1}$ in the solid state with respect to the unit cell.

\section{Conclusion}

A novel series of mono-, heterobi-, -tri- and even -tetrametallic transition metal complexes based on the 1,3,5-triethynyl benzene core have successfully been synthesized using different consecutive synthesis methodologies including metathesis, desilylation, dehydrohalogenation, and carbon-carbon cross-coupling reactions. In the thus formed organometallic molecules 1-I3-Br-5-( $\mathrm{FcC} \equiv \mathrm{C})-\mathrm{C}_{6} \mathrm{H}_{3}, \quad 1-\mathrm{Br}-3-(\mathrm{bpyC} \equiv \mathrm{C})-5-(\mathrm{FcC} \equiv \mathrm{C})-\mathrm{C}_{6} \mathrm{H}_{3}, 1,3-(\mathrm{bpyC} \equiv \mathrm{C})_{2}-5-(\mathrm{FcC} \equiv \mathrm{C})-\mathrm{C}_{6} \mathrm{H}_{3}$, 1-(XC $\equiv C)-3-(b p y C \equiv C)-5-(F c C \equiv C)-C_{6} H_{3} \quad\left(X=H, \quad S_{i M e}\right), \quad 1-(H C \equiv C)-3-\left[(C O){ }_{3} C l R e(b p y-\right.$ $\mathrm{C} \equiv \mathrm{C})]-5-(\mathrm{FcC} \equiv \mathrm{C})-\mathrm{C}_{6} \mathrm{H}_{3}, \quad 1-\left[\left(\mathrm{Ph}_{3} \mathrm{P}\right) \mathrm{AuC} \equiv \mathrm{C}\right]-3-\left[(\mathrm{CO})_{3} \mathrm{ClRe}(\mathrm{bpyC} \equiv \mathrm{C})\right]-5-(\mathrm{FcC} \equiv \mathrm{C})-\mathrm{C}_{6} \mathrm{H}_{3}, \quad 1-$ $\left[\left(\mathrm{Ph}_{3} \mathrm{P}\right) \mathrm{AuC} \equiv \mathrm{C}\right]-3-(\mathrm{bpyC} \equiv \mathrm{C})-5-(\mathrm{FcC} \equiv \mathrm{C})-\mathrm{C}_{6} \mathrm{H}_{3}, \quad\left[1-\left[\left(\mathrm{Ph}_{3} \mathrm{PAuC} \equiv \mathrm{C}\right]-3-\left[\left\{[\mathrm{Ti}](\mathrm{C} \equiv \mathrm{CSiMe})_{2}\right\} \mathrm{Cu}-\right.\right.\right.$ $\left.(\mathrm{bpy}-\mathrm{C} \equiv \mathrm{C})]-5-(\mathrm{FcC} \equiv \mathrm{C})-\mathrm{C}_{6} \mathrm{H}_{3}\right] \mathrm{PF}_{6}$, and $\left[1,3-\left[\left(t-\mathrm{Bu}_{2} \mathrm{bpy}\right)_{2} \mathrm{Ru}(\mathrm{bpy}-\mathrm{C} \equiv \mathrm{C})\right]_{2}-5-(\mathrm{FcC} \equiv \mathrm{C})-\mathrm{C}_{6} \mathrm{H}_{3}\right]-$ $\left(\mathrm{PF}_{6}\right)_{4}\left(\mathrm{Fc}=\left(\eta^{5}-\mathrm{C}_{5} \mathrm{H}_{4}\right)\left(\eta^{5}-\mathrm{C}_{5} \mathrm{H}_{5}\right) \mathrm{Fe}\right.$, bpy $=2,2$-bipyridiyl-5-yl, $t$-Bu $\mathrm{Bu}_{2}$ bpy $=4,4$-di-tert. -butyl2,2-bipyridyl, $\left.[\mathrm{Ti}]=\left(\eta^{5}-\mathrm{C}_{5} \mathrm{H}_{4} \mathrm{SiMe}_{3}\right)_{2} \mathrm{Ti}\right)$ the corresponding transition metal atoms are connected by a $\pi$-conjugated triethynyl benzene backbone and bipyridyl-5-yl ligands. The X-ray crystal structure analysis of two compounds has also been determined showing the characteristic features expected for this type of molecules. Noteworthy is the formation of 1D chains in the solid state of $1-\mathrm{I}-3-\mathrm{Br}-5-(\mathrm{FcC} \equiv \mathrm{C})-\mathrm{C}_{6} \mathrm{H}_{3}$ and $1-(\mathrm{HC} \equiv \mathrm{C})-3-\left(\mathrm{C} \equiv \mathrm{C}-\mathrm{bpy}\left(\mathrm{Re}(\mathrm{CO}){ }_{3} \mathrm{Cl}\right)\right)-5-$ $(\mathrm{FcC} \equiv \mathrm{C})-\mathrm{C}_{6} \mathrm{H}_{3}$, respectively, set up by strong $\pi$ - $\pi$-interactions between aromatic rings of adjacent molecules.

\section{Experimental Part}

Materials and Methods 
Trimethylsilylacetylene [16], 1,3- $\mathrm{Br}_{2}-5-(\mathrm{FcC} \equiv \mathrm{C})-\mathrm{C}_{6} \mathrm{H}_{3}(3)$ [7, 17], ethynylferrocene (2) [18], 5-ethynyl-2,2`-bipyridine (5) [19], [( $\left.\left.\mathrm{Ph}{ }_{3} \mathrm{P}\right) \mathrm{AuCl}\right](\mathbf{1 2})$ [14], $\left[\mathrm{Re}(\mathrm{CO})_{5} \mathrm{Cl}\right](\mathbf{1 0})$ [20] and $\left[\left\{[\mathrm{Ti}]\left(\mu-\sigma, \pi-\mathrm{C} \equiv \mathrm{CSiMe}_{3}\right)_{2}\right\} \mathrm{Cu}(\mathrm{N} \equiv \mathrm{CMe})\right] \mathrm{PF}_{6}(\mathbf{1 5})[12]$ were prepared following published procedures. All other chemicals are commercially available and were used as received.

All reactions were carried out under an atmosphere of purified nitrogen using standard Schlenk techniques. $n$-Hexane and tetrahydrofuran were purified by distillation from sodium/benzophenone ketyl; dichloromethane was purified by distillation from phosphorus pentoxide. Triethylamine was dried by distillation from $\mathrm{KOH}$. Infrared spectra were recorded with a Perkin Elmer FT-IR 1000 spectrometer. NMR spectra were recorded with a Bruker Avance 250 spectrometer. ${ }^{1} \mathrm{H}$ NMR spectra were recorded at $250.130 \mathrm{MHz}$ (internal standard, relative to $\mathrm{CDCl}_{3}, \delta 7.26$ ) and ${ }^{13} \mathrm{C}\left\{{ }^{1} \mathrm{H}\right\} \mathrm{NMR}$ spectra at $62.902 \mathrm{MHz}$ (internal standard, relative to $\mathrm{CDCl}_{3}, \delta$ 77.16). Chemical shifts are reported in $\delta$ units (parts per million) downfield from tetramethylsilane with the solvent as the reference signal. ${ }^{31} \mathrm{P}\left\{{ }^{1} \mathrm{H}\right\} \mathrm{NMR}$ spectra were recorded at $101.254 \mathrm{MHz}$ with $\mathrm{P}\left(\mathrm{OMe}_{3}\right)$ as external standard ( $\delta 139 \mathrm{ppm}$, relative to $85 \%$ $\mathrm{H}_{3} \mathrm{PO}_{4}, \delta 0.00$ ). Elemental analyses were performed with a Vario EL analyzer from Elementar Analysensysteme GmbH (Hanau). Melting points were determined using sealed nitrogen purged capillaries on a Gallenkamp MFB 595010 M melting point apparatus.

Synthesis of 1-I-3-Br-5-(FcC $\equiv C)-C_{6} H_{3}(4)$

To a tetrahydrofuran solution $(50 \mathrm{~mL})$ containing 1,3- $\mathrm{Br}_{2}-5-(\mathrm{FcC} \equiv \mathrm{C})-\mathrm{C}_{6} \mathrm{H}_{3}(3)(1.0 \mathrm{~g}, 2.25$ mmol) was slowly added $1.41 \mathrm{~mL}(2.25 \mathrm{mmol})$ of $n$-BuLi $(1.6 \mathrm{M}$ in $n$-hexane $)$ at $-80{ }^{\circ} \mathrm{C}$. Afterwards, the reaction solution was stirred for 1.5 hours at this temperature and then a solution of $\mathrm{I}_{2}(0.65 \mathrm{~g}, 2.56 \mathrm{mmol})$ dissolved in $20 \mathrm{~mL}$ of tetrahydrofuran was added. After removal of the cooling bath, the solution was stirred for $1 \mathrm{~h}$ at $25^{\circ} \mathrm{C}$ and then an aqueous sodiumthiosulfate solution was added to destroy the excess of $\mathrm{I}_{2}$. Afterwards, the reaction mixture 
was extracted three times with dichloromethane $(50 \mathrm{~mL})$ and the combined dichloromethane extracts were dried over $\mathrm{MgSO}_{4}$. Removal of all volatiles in oil-pump vacuum gave a red solid. Yield: $0.99 \mathrm{~g}$ (2.02 mmol, $90 \%$ based on 3$)$.

\author{
Anal. calc. for $\mathrm{C}_{18} \mathrm{H}_{12} \mathrm{BrFeI}$ (490.9) C 44.04, H 2.46: found C 44.83, H $2.72 \%$. IR (KBr, \\ $\left.\mathrm{cm}^{-1}\right): 2196\left(\mathrm{~s}, v_{C \equiv C \mathrm{CF}}\right) .{ }^{1} \mathrm{H} \mathrm{NMR}\left(\delta, \mathrm{CDCl}_{3}\right): 4.25\left(\mathrm{~s}, 5 \mathrm{H}, \mathrm{C}_{5} H_{5}\right), 4.28\left(\mathrm{pt}, J_{\mathrm{HH}}=1.9 \mathrm{~Hz}, 2 \mathrm{H}\right.$, \\ $\left.\mathrm{C}_{5} H_{4}\right), 4.50\left(\mathrm{pt}, J_{\mathrm{HH}}=1.9 \mathrm{~Hz}, 2 \mathrm{H}, \mathrm{C}_{5} H_{4}\right), 7.58\left(\mathrm{pt}, J_{\mathrm{HH}}=1.6 \mathrm{~Hz}, 1 \mathrm{H}, \mathrm{C}_{6} H_{3}\right), 7.75\left(\mathrm{pt}, J_{\mathrm{HH}}=\right.$ \\ $\left.1.6 \mathrm{~Hz}, 1 \mathrm{H}, \mathrm{C}_{6} H_{3}\right), 7.79\left(\mathrm{pt}, J_{\mathrm{HH}}=1.6 \mathrm{~Hz}, 1 \mathrm{H}, \mathrm{C}_{6} H_{3}\right) .{ }^{13} \mathrm{C}\left\{{ }^{1} \mathrm{H}\right\} \mathrm{NMR}\left(\delta, \mathrm{CDCl}_{3}\right): 64.1$ \\ $\left(C^{i} / \mathrm{C}_{5} \mathrm{H}_{4}\right), 69.4\left(C H / \mathrm{C}_{5} \mathrm{H}_{4}\right), 70.2\left(\mathrm{C}_{5} \mathrm{H}_{5}\right), 71.8\left(C H / \mathrm{C}_{5} \mathrm{H}_{4}\right), 82.9(\mathrm{C} \equiv \mathrm{C}), 91.9(\mathrm{C} \equiv \mathrm{C}), 93.9$ \\ $\left(C^{i} / \mathrm{C}_{6} \mathrm{H}_{3}\right), 122.7\left(C^{i} / \mathrm{C}_{6} \mathrm{H}_{3}\right), 127.7\left(C^{i} / \mathrm{C}_{6} \mathrm{H}_{3}\right), 133.4\left(C H / \mathrm{C}_{6} \mathrm{H}_{3}\right), 138.6\left(C H / \mathrm{C}_{6} \mathrm{H}_{3}\right), 138.8$ \\ $\left(\mathrm{CH} / \mathrm{C}_{6} \mathrm{H}_{3}\right)$.
}

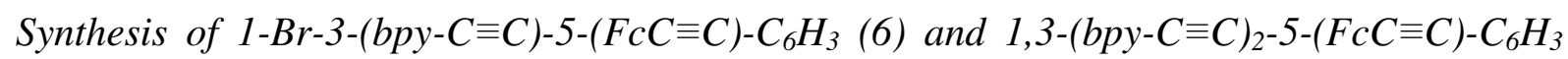
(7)

$500 \mathrm{mg}(1.02 \mathrm{mmol})$ of $1-\mathrm{I}-3-\mathrm{Br}-5-(\mathrm{FcC} \equiv \mathrm{C})-\mathrm{C}_{6} \mathrm{H}_{3}(\mathbf{4})$ and $185 \mathrm{mg}(1.03 \mathrm{mmol})$ of 5ethynyl-2,2-bipyridine (5) were dissolved in $40 \mathrm{~mL}$ of diisopropylamine and $35 \mathrm{mg}$ (5 mol$\%)$ of $\left[\left(\mathrm{Ph}_{3} \mathrm{P}\right)_{2} \mathrm{PdCl}_{2}\right]$ and $18 \mathrm{mg}(10 \mathrm{~mol}-\%)$ of $[\mathrm{CuI}]$ were added in a single portion. The thus obtained reaction mixture was stirred for 3 hours at ambient temperature and than at $40{ }^{\circ} \mathrm{C}$ for 12 hours. Afterwards, all volatile materials were evaporated in vacuum and the residue was purified by column chromatography (Silica gel, diethyl ether-petroleum ether of ratio 1:1, $v / v)$. The first fraction contained non-reacted 4. The second orange fraction contained compound 6 and the third one organometallic 7. Yield: Complex 6: $430 \mathrm{mg}(0.79 \mathrm{mmol}, 78 \%$ based on 4); complex 7: $45 \mathrm{mg}(0.07 \mathrm{mmol}, 7 \%$ based on 4). 
Compound 6: Anal. calc. for $\mathrm{C}_{30} \mathrm{H}_{19} \mathrm{BrFeN}_{2}$ (543.24) C 66.33, H 3.53, N 5.16; found C 66.38, H 3.77, N $4.76 \%$. IR $\left(\mathrm{KBr}, \mathrm{cm}^{-1}\right): 2211\left(\mathrm{~m}, v_{\mathrm{C} \equiv \mathrm{C}}\right) .{ }^{1} \mathrm{H}$ NMR $\left(\delta, \mathrm{CDCl}_{3}\right): 4.26(\mathrm{~s}, 5 \mathrm{H}$, $\left.\mathrm{C}_{5} H_{5}\right), 4.28\left(\mathrm{pt}, J_{\mathrm{HH}}=1.9 \mathrm{~Hz}, 2 \mathrm{H}, \mathrm{C}_{5} H_{4}\right), 4.51\left(\mathrm{pt}, J_{\mathrm{HH}}=1.9 \mathrm{~Hz}, 2 \mathrm{H}, \mathrm{C}_{5} H_{4}\right), 7.32(\mathrm{ddd}$, $\left.{ }^{3} J_{\mathrm{H} 5^{\prime} \mathrm{H} 4^{\prime}}=7.8 \mathrm{~Hz},{ }^{3} J_{\mathrm{H} 5^{\prime} \mathrm{H}^{\prime}}=4.7 \mathrm{~Hz},{ }^{4} J_{\mathrm{H} 5^{\prime} \mathrm{H} 3^{\prime}}=1.0 \mathrm{~Hz}, 1 \mathrm{H}, \mathrm{H} 5^{\prime} / \mathrm{bpy}\right), 7.60-7.64(\mathrm{~m}, 3 \mathrm{H}$, $\left.\mathrm{C}_{6} H_{3}\right), 7.83\left(\mathrm{ddd},{ }^{3} J_{\mathrm{H}^{\prime}{ }^{\prime} \mathrm{H} 3^{\prime}}={ }^{3} J_{\mathrm{H}^{\prime}{ }^{\prime} \mathrm{H} 5^{\prime}}=7.8 \mathrm{~Hz},{ }^{4} J_{\mathrm{H}^{\prime}{ }^{\prime} \mathrm{H} 6^{\prime}}=1.7 \mathrm{~Hz}, 2 \mathrm{H}, H 4^{\prime} / \mathrm{bpy}\right), 7.93\left(\mathrm{dd},{ }^{3} J_{\mathrm{H} 4 \mathrm{H} 3}\right.$

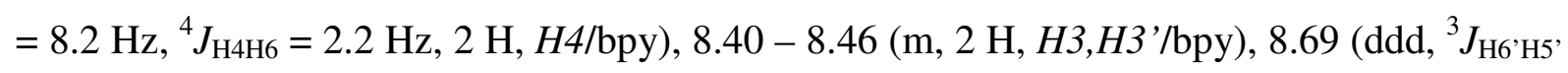
$\left.=4.7 \mathrm{~Hz},{ }^{4} J_{\mathrm{H} 6^{\prime} \mathrm{H}^{\prime}}=1.7 \mathrm{~Hz},{ }^{5} J_{\mathrm{H} 6}{ }^{\prime} \mathrm{H}^{\prime},=1.0 \mathrm{~Hz}, 2 \mathrm{H}, H 6^{\prime} / \mathrm{bpy}\right), 8.80\left(\mathrm{dd},{ }^{4} J_{\mathrm{H} 6 \mathrm{H} 4}=2.2 \mathrm{~Hz},{ }^{5} J_{\mathrm{H} 6 \mathrm{H} 3}\right.$ $=0.6 \mathrm{~Hz}, 2 \mathrm{H}, \mathrm{H6} / \mathrm{bpy}) .{ }^{13} \mathrm{C}\left\{{ }^{1} \mathrm{H}\right\} \operatorname{NMR}\left(\delta, \mathrm{CDCl}_{3}\right): 64.3\left(C^{i} / \mathrm{C}_{5} \mathrm{H}_{4}\right), 69.3\left(C H / \mathrm{C}_{5} \mathrm{H}_{4}\right), 70.2$ $\left(\mathrm{C}_{5} \mathrm{H}_{5}\right), 71.7\left(\mathrm{CH} / \mathrm{C}_{5} \mathrm{H}_{4}\right), 83.6(\mathrm{C} \equiv \mathrm{C}), 88.1(\mathrm{C} \equiv \mathrm{C}), 91.3(\mathrm{C} \equiv \mathrm{C}), 91.4(\mathrm{C} \equiv \mathrm{C}), 119.7(\mathrm{C} 5 / \mathrm{bpy})$, 120.5 (C3/bpy), 121.5 (C3'/bpy), $122.1\left(C^{i} / \mathrm{C}_{6} \mathrm{H}_{3}\right), 124.2\left(C 5^{\prime} / \mathrm{bpy}\right), 124.7\left(C^{i} / \mathrm{C}_{6} \mathrm{H}_{3}\right), 126.3$ $\left(C^{i} / \mathrm{C}_{6} \mathrm{H}_{3}\right), 133.1\left(\mathrm{CH} / \mathrm{C}_{6} \mathrm{H}_{3}\right), 133.3\left(\mathrm{CH} / \mathrm{C}_{6} \mathrm{H}_{3}\right), 134.3\left(\mathrm{CH} / \mathrm{C}_{6} \mathrm{H}_{3}\right), 137.1$ (C4 $\left./ \mathrm{bpy}\right), 139.6$ (C4/bpy), 149.5 (C6 ‘bpy), 151.8 (C6/bpy), 155.4 ( $\left.C^{i} / \mathrm{bpy}\right), 155.5$ ( $\left.C^{i} / \mathrm{bpy}\right)$.

Compound 7. Anal. calc. for $\mathrm{C}_{42} \mathrm{H}_{26} \mathrm{FeN}_{4}$ (642.54) C 78.51, H 4.08, N 8.72; found C 78.56, $\mathrm{H} 4.22, \mathrm{~N} 8.51 \%$. IR $\left(\mathrm{KBr}, \mathrm{cm}^{-1}\right): 2214\left(\mathrm{~m}, \mathrm{v}_{\mathrm{C} \equiv \mathrm{C}}\right) .{ }^{1} \mathrm{H} \mathrm{NMR}\left(\delta, \mathrm{CDCl}_{3}\right): 4.27\left(\mathrm{~s}, 5 \mathrm{H}, \mathrm{C}_{5} H_{5}\right)$, $4.28\left(\mathrm{pt}, J_{\mathrm{HH}}=1.9 \mathrm{~Hz}, 2 \mathrm{H}, \mathrm{C}_{5} H_{4}\right), 4.53\left(\mathrm{pt}, J_{\mathrm{HH}}=1.9 \mathrm{~Hz}, 2 \mathrm{H}, \mathrm{C}_{5} H_{4}\right), 7.33\left(\mathrm{ddd},{ }^{3} J_{\mathrm{H} 5^{\prime} \mathrm{H} 4}{ }^{\prime}=7.9\right.$ $\left.\mathrm{Hz},{ }^{3} J_{\mathrm{H} 5^{\prime} \mathrm{H} 6^{\prime}}=4.7 \mathrm{~Hz},{ }^{4} J_{\mathrm{H} 5^{\prime} \mathrm{H} 3^{\prime}}=1.0 \mathrm{~Hz}, 1 \mathrm{H}, H 5^{\prime} / \mathrm{bpy}\right), 7.67-7.71\left(\mathrm{~m}, 3 \mathrm{H}, \mathrm{C}_{6} H_{3}\right), 7.83$ (ddd, $\left.{ }^{3} J_{\mathrm{H}^{\prime}{ }^{\prime} 3^{\prime}}={ }^{3} J_{\mathrm{H}^{\prime}{ }^{\prime} 5^{\prime}}=7.9 \mathrm{~Hz},{ }^{4} J_{\mathrm{H}^{\prime}{ }^{\prime} \mathrm{H} 6^{\prime}}=1.7 \mathrm{~Hz}, 1 \mathrm{H}, H 4^{\prime} / \mathrm{bpy}\right), 7.94\left(\mathrm{dd},{ }^{3} J_{\mathrm{H} 4 \mathrm{H} 3}=8.2 \mathrm{~Hz},{ }^{4} J_{\mathrm{H} 4 \mathrm{H} 6}\right.$ $=2.0 \mathrm{~Hz}, 2 \mathrm{H}, H 4 / \mathrm{bpy}), 8.43\left(\mathrm{ddd},{ }^{3} J_{\mathrm{H} 3^{\prime} \mathrm{H} 4^{\prime}}=7.9 \mathrm{~Hz},{ }^{4} J_{\mathrm{H} 3^{\prime} \mathrm{H} 5^{\prime}}={ }^{5} J_{\mathrm{H} 3^{\prime} \mathrm{H} 6^{\prime}}=1.0 \mathrm{~Hz}, 2 \mathrm{H}\right.$, $\left.H 3^{\prime} / \mathrm{bpy}\right), 8.44\left(\mathrm{dd},{ }^{3} J_{\mathrm{H} 3 \mathrm{H} 4}=8.2 \mathrm{~Hz},{ }^{5} J_{\mathrm{H} 3 \mathrm{H} 6}=0.8 \mathrm{~Hz}, 2 \mathrm{H}, H 3 / \mathrm{bpy}\right), 8.70\left(\mathrm{ddd},{ }^{3} J_{\mathrm{H} 6}{ }^{\prime}{ }{ }^{\prime}=4.7\right.$ $\left.\mathrm{Hz},{ }^{4} J_{\mathrm{H}^{\prime} \mathrm{H}^{\prime}}=1.7 \mathrm{~Hz},{ }^{5} J_{\mathrm{H} 6^{\prime} \mathrm{H} 3}{ }^{\prime}=1.0 \mathrm{~Hz}, 2 \mathrm{H}, H 6^{\prime} / \mathrm{bpy}\right), 8.83\left(\mathrm{dd},{ }^{4} J_{\mathrm{H} 6 \mathrm{H} 4}=2.2 \mathrm{~Hz},{ }^{5} J_{\mathrm{H} 6 \mathrm{H} 3}=0.8\right.$ $\mathrm{Hz}, 2 \mathrm{H}, H 6 / \mathrm{bpy}) .{ }^{13} \mathrm{C}\left\{{ }^{1} \mathrm{H}\right\} \mathrm{NMR}\left(\delta, \mathrm{CDCl}_{3}\right): 64.5\left(C^{i} / \mathrm{C}_{5} \mathrm{H}_{4}\right), 69.3\left(C H / \mathrm{C}_{5} \mathrm{H}_{4}\right), 70.2\left(\mathrm{C}_{5} \mathrm{H}_{5}\right)$, $71.7\left(C H / \mathrm{C}_{5} \mathrm{H}_{4}\right), 84.1(\mathrm{C} \equiv \mathrm{C}), 87.7(\mathrm{C} \equiv \mathrm{C}), 90.6(\mathrm{C} \equiv \mathrm{C}), 92.0(\mathrm{C} \equiv \mathrm{C}), 119.9(\mathrm{C} 5 / \mathrm{bpy}), 120.5$ (C3/bpy), $121.5\left(C 3^{\prime} / \mathrm{bpy}\right), 123.6\left(C^{i} / \mathrm{C}_{6} \mathrm{H}_{3}\right), 124.2\left(C 5^{\prime} / \mathrm{bpy}\right), 125.2\left(C^{i} / \mathrm{C}_{6} \mathrm{H}_{3}\right), 133.6$ $\left(\mathrm{CH} / \mathrm{C}_{6} \mathrm{H}_{3}\right), 134.5\left(\mathrm{CH} / \mathrm{C}_{6} \mathrm{H}_{3}\right), 137.1$ (C4\%/bpy), 139.6 (C4/bpy), 149.5 (C6\%/bpy), 151.9 (C6/bpy), 155.3 ( $\left.C^{i} / \mathrm{bpy}\right), 155.5$ ( $\left.C^{i} / \mathrm{bpy}\right)$. 
Synthesis of 1-(Me $\mathrm{SiC} \equiv C)-3-(b p y-C \equiv C)-5-(F c C \equiv C)-C_{6} H_{3}(\boldsymbol{8})$

To $400 \mathrm{mg}(0.74 \mathrm{mmol})$ of 1-Br-3-(bpy-C $\equiv \mathrm{C})-5-(\mathrm{FcC} \equiv \mathrm{C})-\mathrm{C}_{6} \mathrm{H}_{3}(\mathbf{6})$ dissolved in $30 \mathrm{~mL}$ of diisopropylamine were added $350 \mathrm{mg}(3.57 \mathrm{mmol})$ of trimethylsilylacetylene, $25 \mathrm{mg}$ (5 mol$\%)$ of $\left[\left(\mathrm{Ph}_{3} \mathrm{P}\right)_{2} \mathrm{Cl}_{2} \mathrm{Pd}\right]$ and $13 \mathrm{mg}(10 \mathrm{~mol}-\%)$ of $[\mathrm{CuI}]$. After stirring this reaction mixture for 20 hours at $50{ }^{\circ} \mathrm{C}$ all volatiles were evaporated in oil-pump vacuum and the residue was chromatographed on Silica gel using a mixture of diethyl ether-petroleum ether $(1: 1, v / v)$ as eluent. After removal of the solvents, complex $\mathbf{8}$ was obtained as an orange solid material. Yield: $355 \mathrm{mg}(0.63 \mathrm{mmol}, 86 \%$ based on $\mathbf{6})$.

Anal. calc. for $\mathrm{C}_{35} \mathrm{H}_{28} \mathrm{FeN}_{2} \mathrm{Si}$ (560.55) C 74.99, H 5.03, N 5.00; found C 74.57, H 5.35, N $4.91 \%$. IR $\left(\mathrm{KBr}, \mathrm{cm}^{-1}\right): 2214\left(\mathrm{~m}, v_{\mathrm{C} \equiv \mathrm{C}}\right), 2157\left(\mathrm{~m}, v_{C \equiv C \mathrm{Si}}\right) .{ }^{1} \mathrm{H} \mathrm{NMR}\left(\delta, \mathrm{CDCl}_{3}\right): 0.26(\mathrm{~s}, 9 \mathrm{H}$, $\left.\mathrm{Si} M e_{3}\right), 4.25\left(\mathrm{~s}, 5 \mathrm{H}, \mathrm{C}_{5} H_{5}\right), 4.27\left(\mathrm{pt}, J_{\mathrm{HH}}=1.9 \mathrm{~Hz}, 2 \mathrm{H}, \mathrm{C}_{5} H_{4}\right), 4.50\left(\mathrm{pt}, J_{\mathrm{HH}}=1.9 \mathrm{~Hz}, 2 \mathrm{H}\right.$, $\left.\mathrm{C}_{5} H_{4}\right), 7.32\left(\mathrm{ddd},{ }^{3} J_{\mathrm{H} 5^{\prime} \mathrm{H} 4^{\prime}}=7.6 \mathrm{~Hz},{ }^{3} J_{\mathrm{H} 5^{\prime} \mathrm{H} 6^{\prime}}=4.8 \mathrm{~Hz},{ }^{4} J_{\mathrm{H}^{\prime}{ }^{\prime} \mathrm{H}^{\prime}}=1.0 \mathrm{~Hz}, 1 \mathrm{H}, \mathrm{H} 5^{\prime} / \mathrm{bpy}\right), 7.58$ $\left(\mathrm{pt}, J_{\mathrm{HH}}=1.6 \mathrm{~Hz}, 1 \mathrm{H}, \mathrm{C}_{6} H_{3}\right), 7.60\left(\mathrm{pt}, J_{\mathrm{HH}}=1.6 \mathrm{~Hz}, 1 \mathrm{H}, \mathrm{C}_{6} H_{3}\right), 7.62\left(\mathrm{pt}, J_{\mathrm{HH}}=1.6 \mathrm{~Hz}, 1 \mathrm{H}\right.$, $\left.\mathrm{C}_{6} H_{3}\right), 7.83\left(\mathrm{ddd},{ }^{3} J_{\mathrm{H}^{\prime}{ }^{\prime} \mathrm{H} 3^{\prime}}={ }^{3} J_{\mathrm{H}^{\prime}{ }^{\prime} \mathrm{H} 5^{\prime}}=7.6 \mathrm{~Hz},{ }^{4} J_{\mathrm{H}^{\prime}{ }^{\prime} \mathrm{H} 6^{\prime}}=1.7 \mathrm{~Hz}, 1 \mathrm{H}, H 4^{\prime} / \mathrm{bpy}\right), 7.92\left(\mathrm{dd},{ }^{3} J_{\mathrm{H} 4 \mathrm{H} 3}\right.$

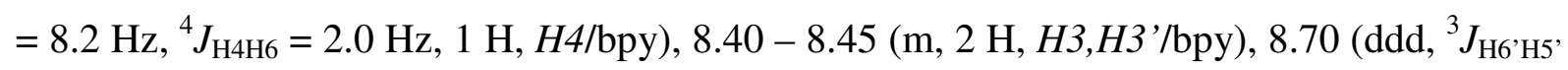
$\left.=4.8 \mathrm{~Hz},{ }^{4} J_{\mathrm{H} 6^{\prime} \mathrm{H}^{\prime}}=1.7 \mathrm{~Hz},{ }^{5} J_{\mathrm{H} 6}{ }^{\prime} \mathrm{H}^{\prime},=1.0 \mathrm{~Hz}, 1 \mathrm{H}, H 6^{\prime} / \mathrm{bpy}\right), 8.80\left(\mathrm{dd},{ }^{4} J_{\mathrm{H} 6 \mathrm{H} 4}=2.0 \mathrm{~Hz},{ }^{5} J_{\mathrm{H} 6 \mathrm{H} 3}\right.$ $=0.8 \mathrm{~Hz}, 1 \mathrm{H}, \mathrm{H6} / \mathrm{bpy}) .{ }^{13} \mathrm{C}\left\{{ }^{1} \mathrm{H}\right\} \operatorname{NMR}\left(\delta, \mathrm{CDCl}_{3}\right): 64.6\left(C^{i} / \mathrm{C}_{5} \mathrm{H}_{4}\right), 69.2\left(C H / \mathrm{C}_{5} \mathrm{H}_{4}\right), 70.2$ $\left(\mathrm{C}_{5} \mathrm{H}_{5}\right), 71.7\left(\mathrm{CH} / \mathrm{C}_{5} \mathrm{H}_{4}\right), 84.2(\mathrm{C} \equiv \mathrm{C}), 87.4(\mathrm{C} \equiv \mathrm{C}), 90.3(\mathrm{C} \equiv \mathrm{C}), 92.1(\mathrm{C} \equiv \mathrm{C}), 96.0(\mathrm{C} \equiv \mathrm{C}), 103.4$ $(\mathrm{C} \equiv \mathrm{C}), 120.0$ (C5/bpy), 120.5 (C3/bpy), 121.5 (C3'/bpy), $123.3\left(C^{i} / \mathrm{C}_{6} \mathrm{H}_{3}\right), 124.10\left(C^{i} / \mathrm{C}_{6} \mathrm{H}_{3}\right)$, $124.14\left(C^{\prime} / \mathrm{bpy}\right), 124.9\left(C^{i} / \mathrm{C}_{6} \mathrm{H}_{3}\right), 133.9\left(C H / \mathrm{C}_{6} \mathrm{H}_{3}\right), 134.2\left(C H / \mathrm{C}_{6} \mathrm{H}_{3}\right), 134.8\left(C H / \mathrm{C}_{6} \mathrm{H}_{3}\right)$, 137.1 (C4\%/bpy), 139.6 (C4/bpy), 149.5 (C6\%/bpy), 151.8 (C6/bpy), 155.3 ( $\left.C^{i} / \mathrm{bpy}\right), 155.6$ ( $\left.C^{i} / \mathrm{bpy}\right)$. 


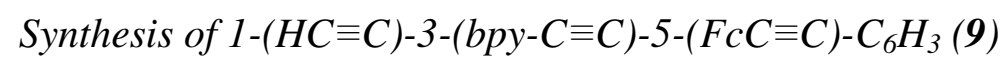

A dichloromethane solution $(25 \mathrm{~mL})$ containing $330 \mathrm{mg}(0.589 \mathrm{mmol})$ of $1-\left(\mathrm{Me}_{3} \mathrm{SiC} \equiv \mathrm{C}\right)-3-$ (bpy-C $\equiv \mathrm{C})-5-(\mathrm{FcC} \equiv \mathrm{C})-\mathrm{C}_{6} \mathrm{H}_{3}(\mathbf{8})$ was cooled to $0{ }^{\circ} \mathrm{C}$ and $0.65 \mathrm{~mL}(0.650 \mathrm{mmol})$ of $\left[n-\mathrm{Bu}_{4} \mathrm{~N}\right] \mathrm{F}$ (1.0 $\mathrm{M}$ in tetrahydrofuran) were slowly added. After removal of the cooling bath, the reaction solution was stirred for $1 \mathrm{~h}$ and then all volatile materials were removed in oil-pump vacuum. The obtained residue was purified on a Silica gel column (diethyl ether-petroleum ether mixture of ratio $3: 2, v / v)$. After removal of the solvents, an orange-red solid was obtained. Yield: $248 \mathrm{mg}(0.508 \mathrm{mmol}, 86 \%$ based on $\mathbf{8})$.

Anal. calc. for $\mathrm{C}_{32} \mathrm{H}_{20} \mathrm{FeN}_{2}$ (488.37) C 78.70, H 4.13, N 5.74; found C 78.49, H 4.41, N 5.62 \%. IR $\left(\mathrm{KBr}, \mathrm{cm}^{-1}\right): 3290\left(\mathrm{~m}, v_{\equiv C-H}\right), 2212\left(\mathrm{~m}, v_{\mathrm{C} \equiv \mathrm{C}}\right), 2100\left(\mathrm{w}, v_{C \equiv C H}\right) .{ }^{1} \mathrm{H}$ NMR $\left(\delta, \mathrm{CDCl}_{3}\right)$ : $3.14(\mathrm{~s}, 1 \mathrm{H}, \equiv \mathrm{CH}), 4.26\left(\mathrm{~s}, 5 \mathrm{H}, \mathrm{C}_{5} H_{5}\right), 4.27\left(\mathrm{pt}, J_{\mathrm{HH}}=1.9 \mathrm{~Hz}, 2 \mathrm{H}, \mathrm{C}_{5} H_{4}\right), 4.51\left(\mathrm{pt}, J_{\mathrm{HH}}=1.9\right.$ $\left.\mathrm{Hz}, 2 \mathrm{H}, \mathrm{C}_{5} H_{4}\right), 7.33\left(\mathrm{ddd},{ }^{3} J_{\mathrm{H}^{\prime}{ }^{\prime} \mathrm{H} 4^{\prime}}=7.8 \mathrm{~Hz},{ }^{3} J_{\mathrm{H}^{\prime}{ }^{\prime} \mathrm{H}{ }^{\prime}}=4.7 \mathrm{~Hz},{ }^{4} J_{\mathrm{H}^{\prime}{ }^{\prime} \mathrm{H}{ }^{\prime}}=1.0 \mathrm{~Hz}, 1 \mathrm{H}\right.$, $\left.H 5^{\prime} / \mathrm{bpy}\right), 7.59\left(\mathrm{pt}, J_{\mathrm{HH}}=1.6 \mathrm{~Hz}, 1 \mathrm{H}, \mathrm{C}_{6} H_{3}\right), 7.61\left(\mathrm{pt}, J_{\mathrm{HH}}=1.6 \mathrm{~Hz}, 1 \mathrm{H}, \mathrm{C}_{6} H_{3}\right), 7.66\left(\mathrm{pt}, J_{\mathrm{HH}}\right.$ $\left.=1.6 \mathrm{~Hz}, 1 \mathrm{H}, \mathrm{C}_{6} H_{3}\right), 7.84\left(\mathrm{ddd},{ }^{3} J_{\mathrm{H}^{4}{ }^{\prime} \mathrm{H}^{\prime}}{ }^{\prime}={ }^{3} J_{\mathrm{H}^{4}{ }^{\prime} \mathrm{H} 5^{\prime}}=7.8 \mathrm{~Hz},{ }^{4} J_{\mathrm{H}^{\prime} \mathrm{H}^{\prime}}=1.7 \mathrm{~Hz}, 1 \mathrm{H}, \mathrm{H} 4^{\prime} / \mathrm{bpy}\right)$, $7.94\left(\mathrm{dd},{ }^{3} J_{\mathrm{H} 4 \mathrm{H} 3}=8.2 \mathrm{~Hz},{ }^{4} J_{\mathrm{H} 4 \mathrm{H} 6}=2.2 \mathrm{~Hz}, 1 \mathrm{H}, H 4 / \mathrm{bpy}\right), 8.40-8.46\left(\mathrm{~m}, 2 \mathrm{H}, H 3, H 3{ }^{\prime} / \mathrm{bpy}\right)$, $8.70\left(\mathrm{ddd},{ }^{3} J_{\mathrm{H} 6^{\prime} \mathrm{H} 5^{\prime}}=4.7 \mathrm{~Hz},{ }^{4} J_{\mathrm{H} 6^{\prime} \mathrm{H}^{\prime}}=1.7 \mathrm{~Hz},{ }^{5} J_{\mathrm{H} 6^{\prime} \mathrm{H}^{\prime}}=1.0 \mathrm{~Hz}, 1 \mathrm{H}, \mathrm{H6}{ }^{\prime} / \mathrm{bpy}\right), 8.81$ (dd, $\left.{ }^{4} J_{\mathrm{H} 6 \mathrm{H} 4}=2.2 \mathrm{~Hz},{ }^{5} J_{\mathrm{H} 6 \mathrm{H} 3}=0.8 \mathrm{~Hz}, 1 \mathrm{H}, H 6 / \mathrm{bpy}\right) .{ }^{13} \mathrm{C}\left\{{ }^{1} \mathrm{H}\right\} \mathrm{NMR}\left(\delta, \mathrm{CDCl}_{3}\right): 64.5\left(C^{i} / \mathrm{C}_{5} \mathrm{H}_{4}\right)$, $69.3\left(\mathrm{CH} / \mathrm{C}_{5} \mathrm{H}_{4}\right), 70.2\left(\mathrm{C}_{5} \mathrm{H}_{5}\right), 71.7\left(\mathrm{CH} / \mathrm{C}_{5} \mathrm{H}_{4}\right), 78.7(\mathrm{C} \equiv \mathrm{C}), 82.2(\mathrm{C} \equiv \mathrm{C}), 84.1(\mathrm{C} \equiv \mathrm{C}), 87.7$ $(\mathrm{C} \equiv \mathrm{C}), 90.6(\mathrm{C} \equiv \mathrm{C}), 92.0(\mathrm{C} \equiv \mathrm{C}), 119.9$ (C5/bpy), 120.5 (C3/bpy), $121.6\left(C 3^{\prime} / \mathrm{bpy}\right), 123.1$ $\left(C^{i} / \mathrm{C}_{6} \mathrm{H}_{3}\right), 123.5\left(C^{i} / \mathrm{C}_{6} \mathrm{H}_{3}\right), 124.2\left(C^{\prime} / \mathrm{bpy}\right), 125.1\left(C^{i} / \mathrm{C}_{6} \mathrm{H}_{3}\right), 134.0\left(C H / \mathrm{C}_{6} \mathrm{H}_{3}\right), 134.6$ $\left(\mathrm{CH} / \mathrm{C}_{6} \mathrm{H}_{3}\right), 134.9\left(\mathrm{CH} / \mathrm{C}_{6} \mathrm{H}_{3}\right), 137.1$ (C4\%/bpy), 139.6 (C4/bpy), 149.5 (C6\%/bpy), 151.9 (C6/bpy), 155.3 ( $\left.C^{i} / \mathrm{bpy}\right), 155.5\left(C^{i} / \mathrm{bpy}\right)$.

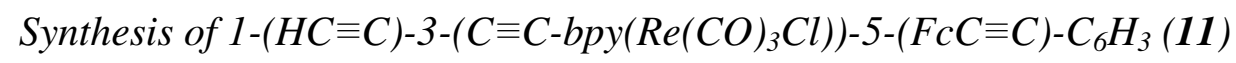


$150 \mathrm{mg}(0.415 \mathrm{mmol})$ of $\left[\mathrm{Re}(\mathrm{CO})_{5} \mathrm{Cl}\right](\mathbf{1 0})$ were dissolved in $70 \mathrm{~mL}$ of toluene at $60{ }^{\circ} \mathrm{C}$. To this solution $230 \mathrm{mg}(0.471 \mathrm{mmol})$ of $1-(\mathrm{HC} \equiv \mathrm{C})-3-(\mathrm{bpy}-\mathrm{C} \equiv \mathrm{C})-5-(\mathrm{FcC} \equiv \mathrm{C})-\mathrm{C}_{6} \mathrm{H}_{3} \quad$ (9) were added in a single portion and stirring was continued for 8 hours at $60{ }^{\circ} \mathrm{C}$ whereby the formed product partly precipitated. After cooling to ambient temperature, the toluene was removed in vacuum and the obtained residue was dissolved in $5 \mathrm{~mL}$ of dichloromethane. Addition of 30 $\mathrm{mL}$ of $n$-hexane resulted in the precipitation of the title compound. After washing the precipitate three times with diethyl ether- $n$-hexane mixtures (ratio 1:1, $/ / v$ ) and drying the orange solid in oil-pump vacuum, $245 \mathrm{mg}(0.309 \mathrm{mmol}, 74 \%$ based on 9) of $\mathbf{1 1}$ could be isolated.

Anal. calc. for $\mathrm{C}_{35} \mathrm{H}_{20} \mathrm{ClFeN}_{2} \mathrm{O}_{3} \mathrm{Re}$ (794.06) C 52.94, H 2.54, N 3.53; found C 53.33, H 2.40, N $3.39 \%$. IR $\left(\mathrm{KBr}, \mathrm{cm}^{-1}\right): 3294\left(\mathrm{~m}, v_{\equiv C-H}\right), 2211\left(\mathrm{~m}, v_{\mathrm{C} \equiv \mathrm{C}}\right), 2022,1914,1894\left(\mathrm{~s}, v_{\mathrm{CO}}\right)$. ${ }^{1} \mathrm{H} \operatorname{NMR}\left(\delta, \mathrm{CDCl}_{3}\right): 4.26\left(\mathrm{~s}, 5 \mathrm{H}, \mathrm{C}_{5} H_{5}\right), 4.28\left(\mathrm{pt}, J_{\mathrm{HH}}=1.9 \mathrm{~Hz}, 2 \mathrm{H}, \mathrm{C}_{5} H_{4}\right), 4.53\left(\mathrm{pt}, J_{\mathrm{HH}}=\right.$ $\left.1.9 \mathrm{~Hz}, 2 \mathrm{H}, \mathrm{C}_{5} H_{4}\right), 7.55\left(\mathrm{ddd},{ }^{3} J_{\mathrm{H} 5^{\prime} \mathrm{H}^{\prime}}=7.6 \mathrm{~Hz},{ }^{3} J_{\mathrm{H}^{\prime}{ }^{\prime} \mathrm{H} 6^{\prime}}=4.6 \mathrm{~Hz},{ }^{4} J_{\mathrm{H}^{\prime}{ }^{\mathrm{H}} 3^{\prime}}=1.0 \mathrm{~Hz}, 1 \mathrm{H}\right.$, $\left.H 5^{\prime} / \mathrm{bpy}\right), 7.62\left(\mathrm{pt}, J_{\mathrm{HH}}=1.6 \mathrm{~Hz}, 1 \mathrm{H}, \mathrm{C}_{6} H_{3}\right), 7.65\left(\mathrm{pt}, J_{\mathrm{HH}}=1.6 \mathrm{~Hz}, 1 \mathrm{H}, \mathrm{C}_{6} H_{3}\right), 7.68\left(\mathrm{pt}, J_{\mathrm{HH}}\right.$ $\left.=1.6 \mathrm{~Hz}, 1 \mathrm{H}, \mathrm{C}_{6} H_{3}\right), 8.01-8.10\left(\mathrm{~m}, 2 \mathrm{H}, H 4, H 4^{\prime} / \mathrm{bpy}\right), 8.14-8.20$ (m, $\left.2 \mathrm{H}, H 3, H 3^{\prime} / \mathrm{bpy}\right)$, $9.07\left(\mathrm{ddd},{ }^{3} J_{\mathrm{H}^{\prime}{ }^{\prime} 5^{\prime}}=4.6 \mathrm{~Hz},{ }^{4} J_{\mathrm{H} 6^{\prime} \mathrm{H}^{\prime}}=1.7 \mathrm{~Hz},{ }^{5} J_{\mathrm{H}^{\prime}{ }^{\prime} \mathrm{H}^{\prime}}=1.0 \mathrm{~Hz}, 1 \mathrm{H}, \mathrm{H6} 6^{\prime} / \mathrm{bpy}\right), 9.15(\mathrm{dd}$, $\left.{ }^{4} J_{\mathrm{H} 6 \mathrm{H} 4}=2.2 \mathrm{~Hz},{ }^{5} J_{\mathrm{H} 6 \mathrm{H} 3}=0.8 \mathrm{~Hz}, 1 \mathrm{H}, H 6 / \mathrm{bpy}\right) .{ }^{13} \mathrm{C}\left\{{ }^{1} \mathrm{H}\right\} \mathrm{NMR}\left(\delta, \mathrm{CDCl}_{3}\right): 64.3\left(C^{i} / \mathrm{C}_{5} \mathrm{H}_{4}\right)$, $69.4\left(\mathrm{CH} / \mathrm{C}_{5} \mathrm{H}_{4}\right), 70.2\left(\mathrm{C}_{5} \mathrm{H}_{5}\right), 71.8\left(\mathrm{CH} / \mathrm{C}_{5} \mathrm{H}_{4}\right), 79.1(\mathrm{C} \equiv \mathrm{C}), 81.8(\mathrm{C} \equiv \mathrm{C}), 83.8(\mathrm{C} \equiv \mathrm{C}), 84.5$ $(\mathrm{C} \equiv \mathrm{C}), 91.2(\mathrm{C} \equiv \mathrm{C}), 96.2(\mathrm{C} \equiv \mathrm{C}), 122.0(C 5 / \mathrm{bpy}), 122.9(C 3 / \mathrm{bpy}), 123.4\left(C^{i} / \mathrm{C}_{6} \mathrm{H}_{3}\right), 123.7$ (C3'/bpy), $124.0\left(C^{i} / \mathrm{C}_{6} \mathrm{H}_{3}\right), 125.4\left(C^{i} / \mathrm{C}_{6} \mathrm{H}_{3}\right), 127.3\left(C 5^{\prime} / \mathrm{bpy}\right), 134.1\left(C H / \mathrm{C}_{6} \mathrm{H}_{3}\right), 134.7$ $\left(\mathrm{CH} / \mathrm{C}_{6} \mathrm{H}_{3}\right), 135.9\left(\mathrm{CH} / \mathrm{C}_{6} \mathrm{H}_{3}\right), 139.1$ (C4\%/bpy), 141.0 (C4/bpy), 153.4 (C6\%/bpy), 154.2 ( $\left.C^{i} / \mathrm{bpy}\right), 155.19$ ( $\left.C^{i} / \mathrm{bpy}\right), 155.24$ (C6/bpy), $189.2(\mathrm{CO}), 197.0(\mathrm{CO})$.

Synthesis of $1-\left(\left(P h_{3} P\right) A u C \equiv C\right)-3-\left(C \equiv C-b p y\left(\operatorname{Re}(C O)_{3} C l\right)\right)-5-(F c C \equiv C)-C_{6} H_{3}(13)$

To a tetrahydrofuran $(5 \mathrm{~mL})$ and diethylamine $(15 \mathrm{~mL})$ solution containing $80 \mathrm{mg}(0.101$ $\mathrm{mmol})$ of $1-(\mathrm{HC} \equiv \mathrm{C})-3-\left(\mathrm{C} \equiv \mathrm{C}-\mathrm{bpy}\left(\mathrm{Re}(\mathrm{CO}){ }_{3} \mathrm{Cl}\right)\right)-5-(\mathrm{FcC} \equiv \mathrm{C})-\mathrm{C}_{6} \mathrm{H}_{3} \quad$ (11) and $50 \mathrm{mg} \quad(0.101$ Wiley- $20 \mathrm{cH}$ 
mmol) of $\left[\left(\mathrm{Ph}_{3} \mathrm{P}\right) \mathrm{AuCl}\right](\mathbf{1 2})$ was added $1 \mathrm{mg}$ of $[\mathrm{CuI}]$. After stirring this reaction solution for 15 hours at $25{ }^{\circ} \mathrm{C}$ all volatile materials were evaporated in oil-pump vacuum and the residue was purified by column chromatography (Silica gel, toluene-tetrahydrofuran mixture of ratio $3: 1, v / v)$. The title complex could be eluted as an orange band. After removal of all volatiles oil-pump vacuum an orange solid remained. Yield: $35 \mathrm{mg}$ (0.033 mmol, $33 \%$ based on 11).

Anal. calc. for $\mathrm{C}_{53} \mathrm{H}_{34} \mathrm{AuClFeN}{ }_{2} \mathrm{O}_{3} \mathrm{PRe} \times 1 / 4 \mathrm{C}_{7} \mathrm{H}_{8}$ (1275.33) C 51.56, H 2.85, N 2.20; found C 51.71, H 2.89, N $2.78 \%$. IR $\left(\mathrm{KBr}, \mathrm{cm}^{-1}\right): 2212\left(\mathrm{~m}, v_{\mathrm{C} \equiv \mathrm{C}}\right), 2115\left(\mathrm{w}, \mathrm{v}_{\mathrm{C} \equiv C \mathrm{CAu}}\right), 2021,1915$, $1896\left(\mathrm{~s}, v_{\mathrm{CO}}\right) .{ }^{1} \mathrm{H} \mathrm{NMR}\left(\delta, \mathrm{CDCl}_{3}\right): 2.36\left(\mathrm{~s}, 1 / 4 \times 3 \mathrm{H}, \mathrm{CH}_{3}\right.$, toluene), $4.25\left(\mathrm{~s}, 5 \mathrm{H}, \mathrm{C}_{5} H_{5}\right), 4.27$ (pt, $\left.J_{\mathrm{HH}}=1.9 \mathrm{~Hz}, 2 \mathrm{H}, \mathrm{C}_{5} H_{4}\right), 4.52\left(\mathrm{pt}, J_{\mathrm{HH}}=1.9 \mathrm{~Hz}, 2 \mathrm{H}, \mathrm{C}_{5} H_{4}\right), 7.17(\mathrm{~m}, 1 / 4 \times 3 \mathrm{H}$, toluene), $7.25(\mathrm{~m}, 1 / 4 \times 2 \mathrm{H}$, toluene $), 7.43-7.61\left(\mathrm{~m}, 15 \mathrm{H}\left(\mathrm{C}_{6} H_{5}\right)+1 \mathrm{H}\left(\mathrm{C}_{6} H_{3}\right)+1 \mathrm{H}\left(H_{5}^{\prime} / \mathrm{bpy}\right)\right), 7.63$ $\left(\mathrm{pt}, J_{\mathrm{HH}}=1.6 \mathrm{~Hz}, 1 \mathrm{H}, \mathrm{C}_{6} H_{3}\right), 7.67\left(\mathrm{pt}, J_{\mathrm{HH}}=1.6 \mathrm{~Hz}, 1 \mathrm{H}, \mathrm{C}_{6} H_{3}\right), 8.02-8.20(\mathrm{~m}, 4 \mathrm{H}$, $\left.H 3, H 3^{\prime}, H 4, H 4^{\prime} / \mathrm{bpy}\right), 9.07\left(\mathrm{ddd},{ }^{3} J_{\mathrm{H} 6^{\prime} \mathrm{H} 5}{ }^{\prime}=4.6 \mathrm{~Hz},{ }^{4} J_{\mathrm{H} 6^{\prime} \mathrm{H} 4^{\prime}}=1.7 \mathrm{~Hz},{ }^{5} J_{\mathrm{H} 6} \mathrm{H}^{\prime}{ }^{\prime}=1.0 \mathrm{~Hz}, 1 \mathrm{H}\right.$, $H 6$ ' / bpy), $9.14\left(\mathrm{dd},{ }^{4} J_{\mathrm{H} 6 \mathrm{H} 4}=2.2 \mathrm{~Hz},{ }^{5} J_{\mathrm{H} 6 \mathrm{H} 3}=0.8 \mathrm{~Hz}, 1 \mathrm{H}, H 6 / \mathrm{bpy}\right) .{ }^{31} \mathrm{P}\left\{{ }^{1} \mathrm{H}\right\} \mathrm{NMR}\left(\delta, \mathrm{CDCl}_{3}\right)$ : $41.1(\mathrm{~s}, \mathrm{AuPPh}) . \operatorname{ESI}-\mathrm{MS}(\mathrm{m} / \mathrm{z}): 1253.4\left([\mathrm{M}+\mathrm{H}]^{+}\right)$.

\section{Synthesis of 1-((Ph $\left.\left.{ }_{3} P\right) A u C \equiv C\right)-3-(C \equiv C-b p y)-5-(F c C \equiv C)-C_{6} H_{3}(\mathbf{1 4})$}

$130 \mathrm{mg}(0.263 \mathrm{mmol})$ of $\left.\left[\left(\mathrm{Ph}_{3} \mathrm{P}\right) \mathrm{AuCl}\right] \mathrm{(12}\right)$ and $135 \mathrm{mg}(0.276 \mathrm{mmol})$ of 1-(HC $\left.\equiv \mathrm{C}\right)-3-(\mathrm{bpy}-$ $\mathrm{C} \equiv \mathrm{C})-5-(\mathrm{FcC} \equiv \mathrm{C})-\mathrm{C}_{6} \mathrm{H}_{3}(\mathbf{9})$ were dissolved in tetrahydrofuran $(10 \mathrm{~mL})$ and diethylamine (15 $\mathrm{mL}$ ) and $1 \mathrm{mg}$ of $[\mathrm{CuI}]$ was added at ambient temperature. After 8 hours of stirring at this temperature, all volatiles were evaporated in oil-pump vacuum. Column chromatography of the residue (Silica gel, diethyl ether-dichloromethane mixture of ratio 10:1, v/v) gave an orange band from which 14 could be isolated as an orange solid. Yield: $165 \mathrm{mg}$ (0.174 mmol, $66 \%$ based on 9$)$.

Anal. calc. for $\mathrm{C}_{50} \mathrm{H}_{34} \mathrm{AuFeN}_{2} \mathrm{P}$ (946.62) C 63.44, H 3.62, N 2.96; found C 63.33, H 3.77, N $2.87 \%$. IR $\left(\mathrm{KBr}, \mathrm{cm}^{-1}\right): 2211\left(\mathrm{~m}, v_{\mathrm{C} \equiv \mathrm{C}}\right), 2116\left(\mathrm{w}, v_{C \equiv C A u}\right) .{ }^{1} \mathrm{H}$ NMR $\left(\delta, \mathrm{CDCl}_{3}\right): 4.24(\mathrm{~s}, 5 \mathrm{H}$, 
$\left.\mathrm{C}_{5} H_{5}\right), 4.25\left(\mathrm{pt}, J_{\mathrm{HH}}=1.9 \mathrm{~Hz}, 2 \mathrm{H}, \mathrm{C}_{5} H_{4}\right), 4.50\left(\mathrm{pt}, J_{\mathrm{HH}}=1.9 \mathrm{~Hz}, 2 \mathrm{H}, \mathrm{C}_{5} H_{4}\right), 7.31(\mathrm{ddd}$, $\left.{ }^{3} J_{\mathrm{H} 5}{ }^{\mathrm{H} 4}{ }^{\prime}=7.6 \mathrm{~Hz},{ }^{3} J_{\mathrm{H} 5}{ }^{\mathrm{H} 6}{ }^{\prime}=4.9 \mathrm{~Hz},{ }^{4} J_{\mathrm{H} 5^{\prime} \mathrm{H} 3^{\prime}}=1.0 \mathrm{~Hz}, 1 \mathrm{H}, \mathrm{H} 5^{\prime} / \mathrm{bpy}\right), 7.39-7.64(\mathrm{~m}, 15 \mathrm{H}$ $\left.\left(\mathrm{C}_{6} H_{5}\right)+3 \mathrm{H}\left(\mathrm{C}_{6} H_{3}\right)\right), 7.82\left(\mathrm{ddd},{ }^{3} J_{\mathrm{H}^{\prime} \mathrm{H}^{\prime}}{ }^{\prime}={ }^{3} J_{\mathrm{H} 4^{\prime} \mathrm{H} 5^{\prime}}=7.6 \mathrm{~Hz},{ }^{4} J_{\mathrm{H}^{\prime}{ }^{\prime} \mathrm{H} 6^{\prime}}=1.7 \mathrm{~Hz}, 1 \mathrm{H}, \mathrm{H} 4^{\prime} / \mathrm{bpy}\right)$, $7.92\left(\mathrm{dd},{ }^{3} J_{\mathrm{H} 4 \mathrm{H} 3}=8.2 \mathrm{~Hz},{ }^{4} J_{\mathrm{H} 4 \mathrm{H} 6}=2.2 \mathrm{~Hz}, 1 \mathrm{H}, H 4 / \mathrm{bpy}\right), 8.41\left(\mathrm{dd},{ }^{3} J_{\mathrm{H} 3 \mathrm{H} 4}=8.2 \mathrm{~Hz},{ }^{5} J_{\mathrm{H} 3 \mathrm{H} 6}=\right.$ $0.8 \mathrm{~Hz}, 1 \mathrm{H}, \mathrm{H} 3 / \mathrm{bpy}), 8.42\left(\mathrm{ddd},{ }^{3} J_{\mathrm{H} 3^{\prime} \mathrm{H} 4^{\prime}}=7.6 \mathrm{~Hz},{ }^{4} J_{\mathrm{H} 3^{\prime} \mathrm{H} 5^{\prime}}={ }^{5} J_{\mathrm{H} 3^{\prime} \mathrm{H} 6^{\prime}}=1.0 \mathrm{~Hz}, 1 \mathrm{H}, \mathrm{H} 3^{\prime} / \mathrm{bpy}\right)$, $8.69\left(\mathrm{ddd},{ }^{3} J_{\mathrm{H} 6^{\prime} \mathrm{H} 5^{\prime}}=4.9 \mathrm{~Hz},{ }^{4} J_{\mathrm{H} 6^{\prime} \mathrm{H}^{\prime}}=1.7 \mathrm{~Hz},{ }^{5} J_{\mathrm{H} 6^{\prime} \mathrm{H}^{\prime}},=1.0 \mathrm{~Hz}, 1 \mathrm{H}, H 6^{\prime} / \mathrm{bpy}\right), 8.80(\mathrm{dd}$, $\left.{ }^{4} J_{\mathrm{H} 6 \mathrm{H} 4}=2.2 \mathrm{~Hz},{ }^{5} J_{\mathrm{H} 6 \mathrm{H} 3}=0.8 \mathrm{~Hz}, 1 \mathrm{H}, H 6 / \mathrm{bpy}\right) .{ }^{13} \mathrm{C}\left\{{ }^{1} \mathrm{H}\right\} \mathrm{NMR}\left(\delta, \mathrm{CDCl}_{3}\right): 65.0\left(C^{i} / \mathrm{C}_{5} \mathrm{H}_{4}\right)$, $69.0\left(\mathrm{CH} / \mathrm{C}_{5} \mathrm{H}_{4}\right), 70.2\left(\mathrm{C}_{5} \mathrm{H}_{5}\right), 71.6\left(\mathrm{CH} / \mathrm{C}_{5} \mathrm{H}_{4}\right), 84.7(\mathrm{C} \equiv \mathrm{C}), 86.8(\mathrm{C} \equiv \mathrm{C}), 89.4(\mathrm{C} \equiv \mathrm{C}), 92.8$ $(\mathrm{C} \equiv \mathrm{C}), 102.4\left(\mathrm{~d}, J_{\mathrm{CP}}=27 \mathrm{~Hz}, \mathrm{AuC} \equiv \mathrm{C}\right), 120.3(C 5 / \mathrm{bpy}), 120.4(C 3 / \mathrm{bpy}), 121.5$ (C3’/bpy), $122.9\left(C^{i} / \mathrm{C}_{6} \mathrm{H}_{3}\right), 124.0\left(C 5^{\prime} / \mathrm{bpy}\right), 124.5\left(C^{i} / \mathrm{C}_{6} \mathrm{H}_{3}\right), 125.8(\mathrm{AuC} \equiv \mathrm{C}), 125.9\left(C^{i} / \mathrm{C}_{6} \mathrm{H}_{3}\right), 129.3$ $\left(\mathrm{d},{ }^{3} J_{\mathrm{CP}}=11.4 \mathrm{~Hz}, C^{m} / \mathrm{C}_{6} \mathrm{H}_{5}\right), 129.8\left(\mathrm{~d},{ }^{1} J_{\mathrm{CP}}=56.1 \mathrm{~Hz}, C^{i} / \mathrm{C}_{6} \mathrm{H}_{5}\right), 131.8\left(\mathrm{~d},{ }^{4} J_{\mathrm{CP}}=2.4 \mathrm{~Hz}\right.$, $\left.C^{p} / \mathrm{C}_{6} \mathrm{H}_{5}\right), 132.7\left(C H / \mathrm{C}_{6} \mathrm{H}_{3}\right), 134.4\left(\mathrm{~d},{ }^{1} J_{\mathrm{CP}}=13.8 \mathrm{~Hz}, C^{o} / \mathrm{C}_{6} \mathrm{H}_{5}\right), 134.5\left(C H / \mathrm{C}_{6} \mathrm{H}_{3}\right), 135.6$ (CH/C $\left.\mathrm{C}_{6} \mathrm{H}_{3}\right), 137.1$ (C4\%/bpy), 139.5 (C4/bpy), 149.4 (C6\%/bpy), 151.9 (C6/bpy), 155.0 ( $\left.C^{i} / \mathrm{bpy}\right), 155.6\left(C^{i} / \mathrm{bpy}\right) .{ }^{31} \mathrm{P}\left\{{ }^{1} \mathrm{H}\right\} \mathrm{NMR}\left(\delta, \mathrm{CDCl}_{3}\right): 41.2\left(\mathrm{~s}, \mathrm{Au} P \mathrm{Ph}_{2}\right)$.

Synthesis of $\quad\left[1-\left(\left(\mathrm{Ph}_{3} P\right) A u C \equiv C\right)-3-\left(C \equiv C-b p y\left(\left\{[T i]\left(\mu-\sigma, \pi-C \equiv C \operatorname{SiMe}_{3}\right)_{2}\right\} C u\right)\right)-5-(F c C \equiv C)-\right.$ $\left.\mathrm{C}_{6} \mathrm{H}_{3}\right] P \mathrm{~F}_{6}(\mathbf{1 6})$

To a tetrahydrofuran solution $(25 \mathrm{~mL})$ containing $50 \mathrm{mg}(0.064 \mathrm{mmol})$ of $[\{[\mathrm{Ti}](\mu-\sigma, \pi-$ $\left.\left.\left.\mathrm{C} \equiv \mathrm{CSiMe}_{3}\right)_{2}\right\} \mathrm{Cu}(\mathrm{N} \equiv \mathrm{CMe})\right] \mathrm{PF}_{6}(\mathbf{1 5}), 60 \mathrm{mg}(0.063 \mathrm{mmol})$ of $1-\left(\left(\mathrm{Ph}_{3} \mathrm{P}\right) \mathrm{AuC} \equiv \mathrm{C}\right)-3-(\mathrm{C} \equiv \mathrm{C}-\mathrm{bpy})-$ 5- $(\mathrm{FcC} \equiv \mathrm{C})-\mathrm{C}_{6} \mathrm{H}_{3}(\mathbf{1 4})$ were added in a single portion. During the course of the reaction (3 hours, $25^{\circ} \mathrm{C}$ ) the color of the reaction solution changed from orange to red. After removal of all volatile materials in oil-pump vacuum the residue was dissolved in $3 \mathrm{~mL}$ of dichloromethane and the title complex was precipitated by addition of $20 \mathrm{~mL}$ of $n$-hexane. The obtained precipitate was washed twice with $10 \mathrm{~mL}$ portions of diethyl ether. Drying the solid material in oil-pump vacuum gave $92 \mathrm{mg}(0.055 \mathrm{mmol}, 87 \%$ based on $\mathbf{1 5})$ of $\mathbf{1 6 .}$ 
Anal. calc. for $\mathrm{C}_{76} \mathrm{H}_{78} \mathrm{AuCuF}_{6} \mathrm{FeN}_{2} \mathrm{P}_{2} \mathrm{Si}_{4} \mathrm{Ti} \times 1 / 4 \mathrm{CH}_{2} \mathrm{Cl}_{2}$ (1693.18) C 54.09, H 4.67, N 1.65; found C 54.00, H 4.89, N $1.62 \%$. IR $\left(\mathrm{KBr}, \mathrm{cm}^{-1}\right): 2211\left(\mathrm{~m}, v_{\mathrm{C} \equiv C}\right), 2115\left(\mathrm{w}, v_{C \equiv C A u}\right), 1924(\mathrm{~m}$, $\left.v_{C \equiv C T i}\right) .{ }^{1} \mathrm{H} \operatorname{NMR}\left(\delta, \mathrm{CDCl}_{3}\right):-0.48\left(\mathrm{~s}, 18 \mathrm{H}, \mathrm{Si} M e_{3}\right), 0.28$ (s, $\left.9 \mathrm{H}, \mathrm{Si} M e_{3}\right), 0.30$ (s, $9 \mathrm{H}$, $\left.\mathrm{Si} M e_{3}\right), 4.23\left(\mathrm{~s}, 5 \mathrm{H}, \mathrm{C}_{5} H_{5}\right), 4.25\left(\mathrm{pt}, J_{\mathrm{HH}}=1.9 \mathrm{~Hz}, 2 \mathrm{H}, \mathrm{C}_{5} H_{4}\right), 4.49\left(\mathrm{pt}, J_{\mathrm{HH}}=1.9 \mathrm{~Hz}, 2 \mathrm{H}\right.$, $\left.\mathrm{C}_{5} H_{4}\right), 5.30\left(\mathrm{~s}, 1 / 4 \times 2 \mathrm{H}, \mathrm{CH}_{2} \mathrm{Cl}_{2}\right), 6.27-6.32\left(\mathrm{~m}, 8 \mathrm{H}, \mathrm{C}_{5} H_{4} \mathrm{Si}\right), 7.41-7.57\left(\mathrm{~m}, 15 \mathrm{H}, \mathrm{C}_{6} H_{5}\right)$, $7.59\left(\mathrm{pt}, J_{\mathrm{HH}}=1.6 \mathrm{~Hz}, 1 \mathrm{H}, \mathrm{C}_{6} H_{3}\right), 7.63\left(\mathrm{pt}, J_{\mathrm{HH}}=1.6 \mathrm{~Hz}, 1 \mathrm{H}, \mathrm{C}_{6} H_{3}\right), 7.65\left(\mathrm{pt}, J_{\mathrm{HH}}=1.6 \mathrm{~Hz}\right.$, $\left.1 \mathrm{H}, \mathrm{C}_{6} H_{3}\right), 7.69-7.75$ (m, $1 \mathrm{H}, H 5^{\prime}$ 'bpy), $8.21-8.30$ (m, $\left.2 \mathrm{H}, H 4, H 4^{\prime} / \mathrm{bpy}\right), 8.51-8.69$ (m, $\left.4 \mathrm{H}, H 3, H 3^{\prime}, H 6, H 6^{\prime} / \mathrm{bpy}\right) .{ }^{31} \mathrm{P}\left\{{ }^{1} \mathrm{H}\right\} \mathrm{NMR}\left(\delta, \mathrm{CDCl}_{3}\right):-145.1$ (septublet, ${ }^{1} J_{\mathrm{PF}}=713 \mathrm{~Hz}, P \mathrm{~F}_{6}$ ), $41.1\left(\mathrm{~s}, \mathrm{Au} P \mathrm{Ph}_{2}\right)$. ESI MS (m/z): $1525.3\left(\left[\mathrm{M}-\mathrm{PF}_{6}\right]^{+}\right)$.

Synthesis of 1,3-(C三C-bpy $\left(R u\left(t-B u_{2} b p y\right)_{2}\right)_{2}-5-(F c C \equiv C)-C_{6} H_{3}(18)$

To $60 \mathrm{mg}(0.085 \mathrm{mmol})$ of $\left[\left(t-\mathrm{Bu}_{2} \mathrm{bpy}\right)_{2} \mathrm{Cl}_{2} \mathrm{Ru}\right](\mathbf{1 7})$ dissolved in $25 \mathrm{~mL}$ of ethanol were added $25 \mathrm{mg}(0.039 \mathrm{mmol})$ of $1,3-(\mathrm{bpy}-\mathrm{C} \equiv \mathrm{C})_{2}-5-(\mathrm{FcC} \equiv \mathrm{C})-\mathrm{C}_{6} \mathrm{H}_{3}(7)$ in a single portion and the reaction solution was heated for 20 hours to reflux whereby a color change from purple to red occurred. After cooling to ambient temperature an aqueous solution $(5 \mathrm{~mL})$ of $\left[\mathrm{H}_{4} \mathrm{~N}\right] \mathrm{PF}_{6}(50$ $\mathrm{mg}, 0.307 \mathrm{mmol}$ ) was added and the solid precipitated was separated and washed with water, ethanol, and diethyl ether, and was than dried in oil-pump vacuum. The title complex was obtained as a red solid. Yield: $64 \mathrm{mg}(0.026 \mathrm{mmol}, 66 \%$ based on 7$)$.

Anal. calc. for $\mathrm{C}_{114} \mathrm{H}_{122} \mathrm{FeF}_{24} \mathrm{~N}_{12} \mathrm{P}_{4} \mathrm{Ru}_{2}$ (2499.14) C 54.79, $\mathrm{H}$ 4.96, $\mathrm{N}$ 6.72; found C 55.11, H 4.96, N $6.42 \%$. IR $\left(\mathrm{KBr}, \mathrm{cm}^{-1}\right): 2211\left(\mathrm{~m}, v_{\mathrm{C} \equiv \mathrm{C}}\right) .{ }^{1} \mathrm{H}$ NMR $\left(\delta, \mathrm{d}_{6}\right.$-Aceton): $1.39\left(\mathrm{~s}, 18 \mathrm{H},{ }^{t} \mathrm{Bu}\right)$, $1.40\left(\mathrm{~s}, 18 \mathrm{H},{ }^{t} \mathrm{Bu}\right), 1.44\left(\mathrm{~s}, 9 \mathrm{H},{ }^{t} \mathrm{Bu}\right), 4.26\left(\mathrm{~s}, 5 \mathrm{H}, \mathrm{C}_{5} \mathrm{H}_{5}\right), 4.38\left(\mathrm{pt}, J_{\mathrm{HH}}=1.9 \mathrm{~Hz}, 2 \mathrm{H}, \mathrm{C}_{5} H_{4}\right)$, $4.53\left(\mathrm{pt}, J_{\mathrm{HH}}=1.9 \mathrm{~Hz}, 2 \mathrm{H}, \mathrm{C}_{5} H_{4}\right), 7.48-7.64\left(\mathrm{~m}, \mathrm{bpy} /{ }^{t} \mathrm{Bu}_{2} \mathrm{bpy}\right), 7.82-8.06(\mathrm{~m}$, bpy ${ }^{t} \mathrm{Bu}_{2}$ bpy), $8.21-8.35$ (m, bpy $/{ }^{t} \mathrm{Bu}_{2}$ bpy), $8.80-8.93\left(\mathrm{~m}, \mathrm{bpy} /{ }^{t} \mathrm{Bu}_{2} \mathrm{bpy}\right) .{ }^{31} \mathrm{P}\left\{{ }^{1} \mathrm{H}\right\} \mathrm{NMR}$ $\left(\delta, \mathrm{d}_{6}\right.$-Aceton): $-145.1\left(\right.$ septett, $\left.{ }^{1} J_{\mathrm{PF}}=713 \mathrm{~Hz}, P \mathrm{~F}_{6}\right)$. ESI MS $(\mathrm{m} / \mathrm{z}): 479.2\left(\left[\mathrm{M}-4 \mathrm{PF}_{6}\right]^{4+}\right)$, $639.6\left(\left[\mathrm{M}-4 \mathrm{PF}_{6}-\mathrm{Ru}\left({ }^{t} \mathrm{Bu}_{2} \mathrm{bpy}\right)_{2}\right]^{2+}\right)$. 


\section{X-ray Structure Determination}

The X-ray structure measurements for $\mathbf{4}$ and $\mathbf{1 1}$ were performed with an Oxford Gemini S diffractomter. The structures were solved by direct methods using SHELXS-97 [21] and refined by full-matrix least-square procedures on $\mathrm{F}^{2}$ using SHELXL-97 [22]. All non-hydrogen atoms were refined anisotropically. All hydrogen atom positions were refined using a riding model. In case of $\mathbf{1 1}$ the $\mathrm{CH}_{2} \mathrm{Cl}_{2}$ molecule as noncoordinating packing solvent has been refined disordered on two positions, respectively, with occupation factors of 0.49 (C36, Cl1, $\mathrm{Cl} 2)$ and 0.51 (C36', Cl1', Cl2').

Table 1. Crystal and Intensity Collection Data for $\mathbf{4}$ and 11.

\begin{tabular}{|c|c|c|}
\hline & 4 & 11 \\
\hline Empirical formula & $\mathrm{C}_{18} \mathrm{H}_{12} \mathrm{Cl}_{2} \mathrm{BrFeI}$ & $\mathrm{C}_{36} \mathrm{H}_{22} \mathrm{Cl}_{3} \mathrm{FeN}_{2} \mathrm{O}_{3} \mathrm{Re}$ \\
\hline Formula weight & 490.94 & 878.96 \\
\hline Temperature (K) & $100(2)$ & $110(2)$ \\
\hline Wavelenght $(\AA)$ & 0.71073 & 0.71073 \\
\hline Crystal system & monoclinic & monoclinic \\
\hline Space group & $\mathrm{P} 2{ }_{1} / \mathrm{n}$ & $\mathrm{P} 2 / \mathrm{n}$ \\
\hline$a(\AA)$ & $9.6235(6)$ & $14.0324(9)$ \\
\hline$b(\AA)$ & $13.7445(9)$ & $7.5197(6)$ \\
\hline$c(\AA)$ & $11.9791(8)$ & $32.398(2)$ \\
\hline$\alpha(\operatorname{deg})$ & 90 & 90 \\
\hline$\beta(\mathrm{deg})$ & $94.295(5)$ & $100.613(5)$ \\
\hline$x(\operatorname{deg})$ & 90 & 90 \\
\hline$V\left(\AA^{3}\right)$ & $1580.03(18)$ & $3360.2(4)$ \\
\hline$\rho_{\text {calc }}\left(\mathrm{g} \mathrm{cm}^{-3}\right)$ & 2.064 & 1.737 \\
\hline$F(000)$ & 936 & 1712 \\
\hline Crystal dimensions $\left(\mathrm{mm}^{3}\right)$ & $0.6 \times 0.4 \times 0.1$ & $0.1 \times 0.05 \times 0.03$ \\
\hline$Z$ & 4 & 4 \\
\hline Max., min. transmission & $1.29694,0.61021$ & $1.00000,0.84325$ \\
\hline
\end{tabular}


Absorption coefficient $\left(\mu, \mathrm{mm}^{-1}\right)$

Scan range (deg)

3.01 to 26.08

2.95 to 26.00

Index ranges

$-10 \leq h \leq 11$

$-17 \leq h \leq 15$

$-16 \leq k \leq 16$

$-9 \leq k \leq 9$

$-13 \leq l \leq 14$

$-39 \leq l \leq 39$

Total reflections

7503

25110

Unique reflections

3072

6582

$R$ (int)

0.0216

0.0720

Data/restraints/parameters

3072 / 0 / 190

6582 / 58 / 445

Goodness-of-fit on $F^{2}$

1.075

1.030

$\mathrm{R} 1,{ }^{a} \mathrm{WR} 2^{a}[I \geq 2 \sigma(I)]$

$0.0514,0.1628$

$0.0490,0.0732$

$\mathrm{R} 1,{ }^{a} \mathrm{wR} 2^{a}$ (all data)

$0.0558,0.1658$

$0.1077,0.0883$

Max., min. peak in final Fourier map $\quad 3.066,-2.747$ $1.403,-0.847$

${ }^{a} \mathrm{R} 1=\left[\sum\left(|| F_{\mathrm{o}}|-| F_{\mathrm{c}} \mid\right) / \sum\left|F_{\mathrm{o}}\right|\right) ; w \mathrm{R} 2=\left[\sum\left(w\left(F_{\mathrm{o}}{ }^{2}-F_{\mathrm{c}}{ }^{2}\right)^{2}\right) / \sum\left(w F_{\mathrm{o}}^{4}\right)\right]^{1 / 2} . \mathrm{S}=\left[\sum w\left(F_{\mathrm{o}}{ }^{2}-F_{\mathrm{c}}{ }^{2}\right)^{2}\right] /(n-$ $p)^{1 / 2} \cdot n=$ number of reflections, $p=$ parameters used.

\section{Supplementary Material}

The crystallographic data for $\mathbf{4}$ and $\mathbf{1 1}$ have been deposited with the Cambridge Crystallographic Data Centre as supplementary publication no. CCDC-753340 (4) and CCDC-753341 (11). Copies of this information can be obtained free of charge on application to CCDC, 12 Union Road, Cambridge CB2 1ET, UK. [fax: +44-1223-336033, E-mail: deposit@ ccdc.cam.ac.uk].

\section{Acknowledgement}

Financial support from the Deutsche Forschungsgemeinschaft and the Fonds der Chemischen Industrie is gratefully acknowledged. 


\section{References}

[1] a) N. J. Long, C. K. Williams, Angew. Chem., Int. Ed. 2003, 42, 2586. b) F. Paul, C. Lapinte, Coord. Chem. Rev. 1998, 178, 180. c) C.E. Powell, M.G. Humphrey, Coord. Chem. Rev. 2004, 248, 725. d) V. W. W. Yam, K. K. W. Lo, K. M. C. Wong, J. Organomet. Chem. 1999, 578, 3. e) P. J. Low, Dalton Trans. 2005, 17, 2821; f) M. P. Cifuentes, M. G. Humphrey, J. P. Morall, M. Samoc, F. Paul, T. Roisnel, C. Lapinte, Organometallics 2005, 24, 4280. g) B. S. Brunschwig, C. Creutz, N. Sutin, Chem. Soc. Rev. 2002, 31, 168. h) A. Ceccon, S. Santi, L. Orian, A. Bisello, Coord. Chem. Rev. 2004, 248, 683. i) D. Astruc, Acc. Chem. Res. 1997, 30, 383. j) V. Balzani, S. Campagna, G. Denti, A. Juris, S. Serroni, M. Venturi, Acc. Chem. Res. 1998, 31, 26. k) Q. S. Hu, V. Pugh, M. Sabat, L. Pu, J. Org. Chem. 1999, 64, 7528. 1) K. Onitsuka, M. Fujimoto, H. Kitajima, N. Ohshiro, F. Takei, S. Takahashi, Chem. Eur. J. 2004, 10, 6433. m) N. J. Long, A. J. Martin, F. Fabrizi de Biani, P. Zanello, J. Chem. Soc., Dalton Trans. 1998, 2017. n) M. P. Cifuentes, C. E. Powell, J. P. Morrall, A. M. McDonagh, N. T. Lucas, M. G. Humphrey, M. Samoc, S. Houbrechts, I. Asselberghs, K. Clays, J. Am. Chem. Soc. 2006, 128, 10819. o) M. P. Cifuentes, M. G. Humphrey, J. Organomet. Chem. 2004, 689, 3968. p) S. Szafert, J. A. Gladysz, Chem. Rev. 2006, 106, (2006) 1. q) C. E. Powell, M. P. Cifuentes, M. G. Humphrey, A. C. Willis, J. P. Morrall, M. Samoc, Polyhedron 2007, 26, 284. r) J. Vicente, M. T. Chicote, M. M. Alvarez-Falcon, Organometallics 2005, 24, 2764. s) S. H. F. Chong, S. C. F. Lam, V. W. W. Yam, N. Zhu, K. K. Cheung, S. Fathallah, K. Costuas, J. F. Halet, Organometallics 2004, 23, 4924. t) A. Klein, O. Lavastre, J. Fiedler, Organometallics 2006, 25,635 .

[2] a) Special issue, "50th Anniversary of the Discovery of Ferrocene", J. Organomet. Chem. 2001, 637-639, R. D. Adams. ed., and references cited therein. b) Ferrocenes, 
ed. A. Togni and T. Hayashi, VCH Publishers, New York, 1995. c) Ferrocenes, ed. P. Stepnicka, John Wiley \& Sons, 2008.

[3] a) H. Lang, R. Packheiser, Collect. Czech. Chem. Commun. 2007, 72, 435. b) H. Lang, R. Packheiser, B. Walfort, Organometallics, 2006, 25, 1836. c) R. Packheiser, A. Jakob, P. Ecorchard, B. Walfort, H. Lang, Organometallics 2008, 27, 1214. d) R. Packheiser, P. Ecorchard, T. Rüffer, H. Lang, Organometallics 2008, 27, 3534. e) R. Packheiser, P. Ecorchard, B. Walfort, H. Lang, J. Organomet. Chem. 2008, 693, 933. (f) R. Packheiser, P. Ecorchard, T. Rüffer, B. Walfort, H. Lang, Eur. J. Inorg. Chem. 2008, 4152. g) R. Packheiser, P. Ecorchard, T. Rüffer, H. Lang, Chem. Eur. J. 2008, 14, 4948. h) A. Jakob, P. Ecorchard, K. Köhler, H. Lang, J. Organomet. Chem. 2008, 693, 3479. i) H. Lang, A. Jakob, In Organometallic Chemistry Research Perspectives; R. P. Irwin, ed.; Nova Publishers, 2007, 99.

[4] a) X. H. Wu, S. Jin, J. H. Liang, Z. Y. Li, G. Yu, S. H. Liu, Organometallics 2009, 28, 2450. b) C. Lapinte, J. Organomet. Chem. 2008, 693, 793. c) N. Chawdhury, N. J. Long, M. F. Mahon, L. Ooi, P. R. Raithby, S. Rooke, A. J. P. White, D. J. Williams, M. Younus, J. Organomet. Chem. 2004, 689, 840. d) F. de Montigny, G. Argouarch, K. Costuas, J. F. Halet, T. Roisnel, L. Toupet, C. Lapinte, Organometallics 2005, 24, 4558. e) S. K. Hurst, M. P. Cifuentes, A. M. McDonagh, M. G. Humphrey, M. Samoc, B. Luther-Davies, I. Asselberghs, A. Persoons, J. Organomet. Chem. 2002, 642, 259. f) S. Fraysse, S. Coudret, J. P. Launay, J. Am. Chem. Soc. 2003, 125, 5880. g) T. Weyland, I. Ledoux, S. Brasselet, J. Zyss, C. Lapinte, Organometallics 2000, 19, 5235. (k) M. I. Bruce, B. C. Hall, B. D. Kelly, P. J. Low, B. W. Skelton A. H. J., White, J. Chem. Soc., Dalton Trans. 1999, 3719. 1) S. I. Ghazala, F. Paul, L. Toupet, T. Roisnel, P. Hapiot, C. Lapinte, J. Am. Chem. Soc. 2006, 128, 2463.

[5] a) J. Moussa, M. N. Rager, L. M. Chamoreau, L. Ricard, H. Amouri, Organometallics 2009, 28, 397. b) G. A. Koutsantonis, G. I. Jenkins, P. A. Schauer, B. Szczepaniak, B. 
W. Skelton, C. Tan, A. H. White, Organometallics 2009, 28, 2195. c) S. Santi, L. Orian, A. Donoli, C. Durante, A. Bisello, M. D. Valentin, P. Ganis, F. Benetollo, A. Ceccon, J. Organomet. Chem. 2008, 693, 3797. d) O. Pélerin, C. Olivier, T. Roisnel, D. Touchard, S. Rigaut, J. Organomet. Chem. 2008, 693, 2153. e) S. C. F. Lam, V. W.W. Yam, K. M. C. Wong, E. C. C. Cheng, N. Zhu, Organometallics 2005, 24, 4298. f) M. Samoc, N. Gauthier, M. P. Cifuentes, F. Paul, C. Lapinte, M. G. Humphrey, Angew. Chem. Int. Ed. 2006, 45, 7376. g) K. M. C. Wong, S. C. F. Lam, C. C. Ko, N. Zhu, V. W.-W. Yam, S. Roué, C. Lapinte, S. Fathallah, K. Costuas, S. Kahlal, J. F. Halet, Inorg. Chem. 2003, 42, 7086. h) M. Younus, N. J. Long, P. R. Raithby, J. Lewis, J. Organomet. Chem. 1998, 570, 55. i) M. V. Russo, C. Lo Sterzo, P. Franceschini, G. Biagini, A. Furlani, J. Organomet. Chem. 2001, 619, 49. j) N. Szesni, M. Drexler, J. Maurer, R. F. Winter, F. de Montigny, C. Lapinte, S. Steffens, J. Heck, B. Weibert, H. Fischer, Organometallics 2006, 25, 5774. k) V. W.-W. Yam, W.-Y. Lo, C.-H. Lam, W. K.-M. Fung, K. M.-C. Wong, V. C.-Y. Lau, N. Zhu, Coord. Chem. Rev. 2003, 245, 39.

[6] a) R. Packheiser, M. Lohan, B. Bräuer, F. Justaud, C. Lapinte, H. Lang, J. Organomet. Chem. 2008, 693, 2898. b) M. Lohan, P. Ecorchard, T. Rüffer, F. Justaud, C. Lapinte, H. Lang, Organometallics 2009, 28, 1878. c) Y. Fan, I. P.-C. Liu, P. E. Fanwick, T. Ren, Organometallics 2009, 28, 3959. d) K. Kowalski, M. Linseis, R. F. Winter, M. Zabel, S. Záliš, H. Kelm, H.-J. Krüger, B. Sarkar, W. Kaim, Organometallics 2009, 28, 4196. e) T.-Y. Dong, S.-F. Lin, C.-P. Chen, S.-W. Yeh, H.-Y. Chen, Y.-S. Wen, J. Organomet. Chem. 2009, 694, 1529. f) S. Szafert, F. Paul, W. E. Meyer, J. A. Gladysz, C. Lapinte, C. R. Chim. 2008, 11 693. g) H. Jiao, K. Costuas, J. A. Gladysz, J.-F. Halet, M. Guillemot, L. Toupet, F. Paul, C. Lapinte, J. Am. Chem. Soc. 2003, 125, 9511. h) F. Paul, W. E. Meyer, L. Toupet, H. Jiao, J. A. Gladysz, C. Lapinte, J. Am. Chem. Soc. 2000, 122, 9405. i) H. Jiao, K. Costuas J. A. Gladysz, J.-F. Halet, M. Guillemot Wiley-vch 
L. Toupet F. Paul, C. Lapinte, J. Am. Chem. Soc. 2003, 125, 9511. j) F. de Montigny, G. Argouarch, T. Roisnel, L. Toupet, C. Lapinte, S. C.-F. Lam, C.-H. Tao, V.W.-W. Yam, Organometallics 2008, 27, 1912. k) K. M.-C. Wong, S. C.-F. Lam, C.-C. Ko, N. Zhu, V. W.-W. Yam, S. Roué, C. Lapinte, S. Fathallah, K. Costuas, S. Kahlal, J.-F. Halet, Inorg. Chem. 2003, 42, 7086. 1) F. Paul, B. G. Ellis, M. I. Bruce, L. Toupet, T. Roisnel, K. Costuas, J.-F. Halet, C. Lapinte, Organometallics 2006, 25, 649. m) M. I. Bruce, P. J. Low, F. Hartl, P. A. Humphrey, F. Montigny, M. Jevric, C. Lapinte, G. J. Perkins, R. L. Roberts, B. W. Skelton, A. H. White, Organometallics 2005, 24, 5241. n) M. I. Bruce, K. Costuas, T. Davin, B. G. Ellis, J.-F. Halet, C. Lapinte, P. J. Low, M. E. Smith, B. W. Skelton, L. Toupet, A. H. White, Organometallics 2005, 24, 3864. o) M. I. Bruce, F. de Montigny, M. Jevric, C. Lapinte, B. W. Skelton, M. E. Smith, A. H. White, J. Organomet. Chem. 2004, 689, 2860. p) M. I. Bruce, B. G. Ellis, M. Gaudio, C. Lapinte, G. Melino, F. Paul, B. W. Skelton, M. E. Smith, L. Toupet, A. H. White, Dalton Trans. 2004, 10, 1601.

[7] R. Packheiser, H. Lang, Inorg. Chim. Acta 2010, submitted.

[8] a) J. Vicente, M. T. Chicote, M. D. Abrisqueta, P. G. Jones, Organometallics 1997, 16, 5628. b) M. I. Bruce, E. Horn, J. G. Matisons, M. R. Snow, Aust. J. Chem. 1984, 37, 1163.

[9] a) I. O. Koshevoy, Y.-C. Lin, A. J. Karttunen, P.-T. Chou, P. Vainiotalo, S. P. Tunik, M. Haukka, T. A. Pakkanen, Inorganic Chemistry 2009, 48, 2094. b) W.-Y. Wong, S.Y. Poon, J. Inorg. Organomet. Polym. 2008, 18, 155. c) D. J. Armitt, M. I. Bruce, B. W. Skelton, A. H. White, J. Organomet. Chem. 2008, 693, 3571. d W.-Y. Wong, Y.H. Guo, J. Molecular Structure 2008, 150. e) A. Jakob, P. Ecorchard, M. Linseis, R. F. Winter, H. Lang, J. Organomet. Chem. 2009, 694, 655. f) J. Vicente, J. Gil-Rubio, N. Barquero, P. G. Jones, D. Bautista, Organometallics 2008, 27, 646. g) X. He, N. Zhu, V. W.-W. Yam, Organometallics 2009, 28, 3621. 
[10] a) H. Lang, D. S. A. George, G. Rheinwald, Coord. Chem. Rev. 2000, 206-207, 101. b) H. Lang, G. Rheinwald, J. Prakt. Chem. 1991, 341, 1. c) H. Lang, K. Köhler S., Blau, Coord. Chem. Rev. 1995, 143, 113.

[11] a) P. Kurz, B. Probst, B. Spingler, R. Alberto, Eur. J. Inorg. Chem. 2006, 2966. (b) E. R. Civitello, P. S. Dragovich, T. B. Karpishin, S. G. Novick, G. Bierach, J. F. O’Connell, T. D. Westmoreland, Inorg. Chem. 1993, 32, 237. c) Y.-B. Dong, L. Yang, K.-K. Cheung, A. Mayr, J. Organomet. Chem. 2000, 598, 55. d) H.-B. Xu, L.-Y. Zhang, Z.-N. Chen, Inorg. Chim. Acta 2007, 360, 163. e) M. Wrighton, D. L. Morse, J. Am. Chem. Soc. 1974, 96, 998. (f) T. R. O’Toole, J. N. Younathan, B. P. Sullivan, T. J. Meyer, Inorg. Chem. 1989, 28, 3923. g) P. A. Anderson, F. R. Keene, E. Horn, E. R. T. Tiekink, Appl. Organomet. Chem. 1990, 4, 523.

[12] M. D. Janssen, M. Herres, L. Zsolnai, A. L. Spek, D. M. Grove, H. Lang, G. van Koten, Inorg. Chem. 1996, 35, 2476.

[13] R. Packheiser, B. Walfort, H. Lang, Organometallics 2006, 25, 4579.

[14] M. I. Bruce, E. Horn, J. G. Matisons, M. R. Snow, Aust. J. Chem. 1984, 37, 1163.

[15] a) M. O. Sinnokrot, E. F. Valeev, C. D. Sherrill, J. Am. Chem. Soc. 2002, 124, 10887.

b) Y. Zhao, D. G. Truhlar, J. Phys. Chem. A 2005, 109, 4209. c) T. Dahl, Acta Chem. Scand. 1994, 48, 95.

[16] L. Brandsma, Preparative Acetylenic Chemistry, Elsevier-Verlag, Amsterdam 1998, 114.

[17] H. Fink, N. J. Long, A. J. Martin, G. Opromolla, A. J. P. White, D. J. Williams, P. Zanello, Organometallics 1997, 16, 2646.

[18] J. Polin, H. Schottenberger, Org. Synth. 1996, 13, 262.

[19] a) V. Grosshenny, F. M. Romero, R. Ziessel, J. Org. Chem. 1997, 62, 1491. b) P. F. H. Schwab, F. Fleischer, J. Michl, J. Org. Chem. 2002, 67, 443. c) J. Polin, E. Schmohel, V. Balzani, Synthesis 1998, 3, 321. 
[20] S. P. Schmidt, W. C. Trogler, F. Basolo, Inorg. Synth. 1990, 28, 160.

[21] G. M. Sheldrick, Acta Crystallogr., Sect. A 1990, 46, 467.

[22] G. M. Sheldrick, SHELXL-97, Program for Crystal Structure Refinement, University of Göttingen, 1997. 


\section{Pictogram}

\section{Transition-Metal Complexes Based on the 1,3,5-Triethynyl Benzene Linking Unit}

Rico Packheiser, Tobias Rüffer, Petra Ecorchard, and Heinrich Lang

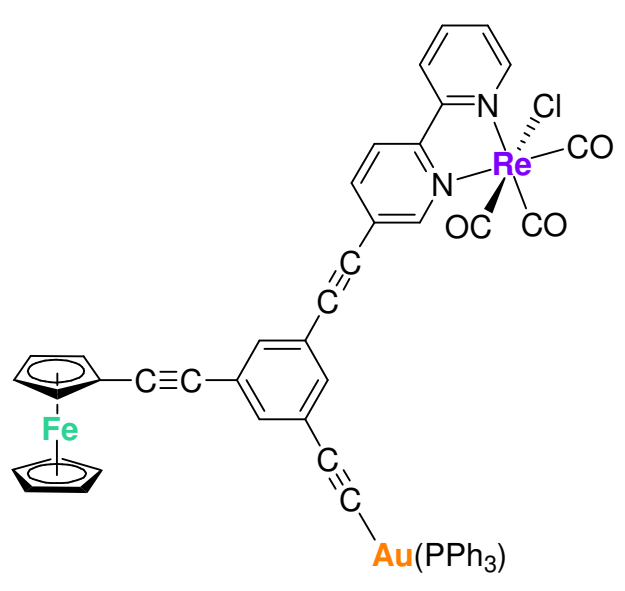




\section{Synopsis \\ Transition-Metal Complexes Based on the 1,3,5-Triethynyl Benzene Linking Unit}

Rico Packheiser, Tobias Rüffer, Petra Ecorchard, and Heinrich Lang

The synthesis and spectroscopic properties of multimetallic transition metal complexes with up to four different metal centers in which the metals are connected by carbon-rich bridging units is discussed. The structure of two molecules in the solid state is reported. 